\title{
Whither Public Interest: The Case of Greece's Public Finances
}

\author{
Thomas Moutos \\ Christos Tsitsikas
}

CESIFO WORKING PAPER NO. 3098

Category 6: Fiscal Policy, Macroeconomics and Growth JUNE 2010

\footnotetext{
An electronic version of the paper may be downloaded

- from the SSRN website: www.SSRN.com

- from the RePEc website: - from the CESifo website: 


\title{
Whither Public Interest: The Case of Greece's Public Finances
}

\begin{abstract}
During the last three decades there has been an almost continuous undermining of the public interest by private interests operating either outside or inside Greek public administration. The result of this infiltration has been a gradual loss of bureaucratic autonomy to pursue the public interest. The web of relationships developed between private interests and the two dominant political parties have eroded both the efficacy of public administration and the dynamism of the private sector as incumbent firms and public (or quasi-public) sector functionaries have been using their power to prevent the birth of new firms and to raid the state coffers. The upshot of these have been the emergence of permanently large budget and current account deficits, which have in turn driven Greece's foreign indebtedness to alarming levels, necessitating the current bailout by the EU/ECB/IMF.
\end{abstract}

JEL-Code: E21, H11, H41, H62, H63.

Keywords: debt, deficits, political economy, fiscal crisis, Greece.

Thomas Moutos

Athens University of Economics and

Business

Greece

tmoutos@aueb.gr
Christos Tsitsikas

Athens University of Economics and

Business

Greece

c.tsitsikas@gmail.com

Date of Submission: May 8, 2010

We wish to thank Margarita Katsimi for providing us with useful comments and suggestions. We wish also to thank an anonymous referee whose comments and suggestions have helped us to improve both the presentation and the substance of the paper. 
How did you go bankrupt?” Bill asked.

“Two ways,” Mike said. "Gradually and then suddenly.”

—Ernest Hemingway, The Sun Also Rises

\section{Introduction}

At the turn of the millennium, the prospects for the Greek economy were anything but dismal. The country had just experienced a few years of high growth and fiscal consolidation (after a dismal economic and fiscal performance from 1980 to 1995), and the European Council in June 2000 had just decided that Greece would be accepted into the Economic and Monetary Union. Following this decision, Prime Minister Costas Simitis confidently predicted that “... this development permits us now to better exploit possibilities provided by European unification and constitutes a qualitative change since it promotes Greece to a higher level,", adding also that "...accession to the euro means greater economic stability, better growth rates and more confidence". Indeed, the average annual growth rate from 2000 to 2008 was almost $4 \%$ per annum. ${ }^{1}$

However, with the onset of the global financial crisis in 2008, Greece's economic situation has been deteriorating at an alarming rate. Although Greece has, so far, avoided the sharp drops in output experienced by many economies as a result of the global economic crisis, the slowdown in output growth has been large. Moreover, other indicators of economic performance point to a protracted period of slow and painful recovery. The existence of huge budget and current account deficits, combined with high levels of government and external debt make it very likely that the following decade will surpass the 1980s as the decade with the worst economic performance since 1950. The decision made by the Greek government on April 23, 2010 to seek financial support from the EU/ECB/IMF in order to be able to roll over its maturing debt obligations testifies to the graveness of the situation.

The problems facing Greece stem from one basic factor, namely the absence of an autonomous and efficient state bureaucracy whose role is to promote and defend the public interest; instead, since Greece's modern reincarnation in the $19^{\text {th }}$ century as a

\footnotetext{
${ }^{1}$ The mood expressed by the Prime Minister was also shared by the majority of the population and the academic community. Pagoulatos (2003) captured this ebullient feeling with these words: "A most impressive transformation involves Greece's position in the EU. Greece is no more the "reluctant partner", the "problem case", the "black sheep" of the Community (to recall just some of the rather uncharitable terms once employed). It has matured to become not just a "normal" country, a "mainstream" EU member, but an ardent and committed European, and (since its 2001 EMU entry) finally a "success story" as well. This graduation from troubled adolescence and marginality to European "normality" and membership to the Eurozone core of Europe not only summarizes the momentous socioeconomic and political transformation of Greece, but it also testifies to the success of the European Union in helping bring about this transformation.”
} 
nation state, the state bureaucracy has been captured by party-political and private interests, whereas it has used its limited autonomy to the benefit of its functionaries (see, Mouzelis, 1978, Mavrogordatos, 2001). The upshot of this has been that during periods in which borrowing was perceived to be easy and cheap (e.g., after Greece's entry into EMU), there was no mechanism to stop debt from accumulating; it was during such periods that the culture of soft budget constraints was legitimized as "rational" response to the new opportunities offered by the low-interest rates and high-growth environment.

In the rest of the paper we shall first present (Section 2) an overview of the evolution of the Greek economy. As we shall see, the end of fast growth in Greece (relative to the other OECD countries) came to a halt at the start of the 1980s. The start of this decade coincided with two events, i.e. Greece's accession to the EEC and the rise of the socialist party (PASOK) to power; as is to be expected in such cases, the relative importance of each factor for the precipitous decline in the growth rate remains a hotly disputed issue (the EEC for forcing an end to the pampered situation under which many Greek industries operated, PASOK for pursuing irresponsible wage and spending policies). The laxity of economic policy during that decade set the bedrock on which subsequent governments (with a brief interlude in the second half of the 1990s) built the tombstone of fiscal irresponsibility which culminated in the present crisis.

The (mostly) lukewarm attempts by the Greek fiscal authorities to put the brakes on further debt accumulation during the last two decades is examined in Section 3. Using the government budget constraint, we separate the influence of four factors to public debt accumulation. These are: (i) the structural component, which measures the contribution of the primary deficit to debt accumulation if the economy is operating at full capacity, (ii) the cyclical component, which measures the contribution that the primary deficit makes to debt accumulation as a result of the economy operating below capacity, (iii) the rate component, which measures the influence of the difference between the (real) interest rate and growth of GDP on the debt ratio, and (iv) the stock-flow adjustment, which, especially in the Greek context, arises from the fact that governments undertake various activities which are not reported in the budget but contribute to debt accumulation. We find that the fiscal authorities have not been able to generate the primary structural surpluses which would have been necessary to offset the effect that the huge stock-flow adjustments had on debt accumulation.

In Section 4 we examine in more detail the separate influence of government spending and government revenue on government deficits. We find that the rise in deficits was not due to a decline in tax revenue, but to a large increase in government spending which occurred in the 1980s. The rise in spending was mainly driven by increases in public sector pay and employment, reflecting the fact that public sector employment has remained a main tool through which political parties in Greece dispense favours to partisan voters, as well a "redistributive" tool in periods of high unemployment. The rise in government revenue followed, sometimes with considerable lag, the rise in government spending. Unlike government spending, whose fastest rise took place in the 1980s (its share in GDP rose by 18 percentage points), government revenue as a share of GDP rose by only 5 percentage points in the 1980s. In an effort to gain EMU entry, the 
distance between spending and revenue was closed significantly in the 1990s through large increases in tax revenue, but EMU entry and the global financial crisis increased the gap once again during the last decade.

The politico-economic factors behind the structure, conduct and performance of the Greek economy in recent decades are explained in Section 5. We contend that a crucial factor in this respect, and which has been steadily eroding the foundations of Greek society and will impact on the resolution of the current fiscal crisis, is the interdependence between the tax burden, public good provision, tax compliance, and sectoral allocation of economic activity. The rise of budget deficits during the last three decades reflect, in addition to outright corruption, the increasing inability of the public sector to deliver on the public goods and services which higher-taxed citizens (i.e., the law-abiding ones who do not evade on their taxes and thus face tax burdens significantly higher than the economy-wide average) have every right to expect in return. This has created a further "legitimization" of tax evasion as more citizens consider that there has been a "breach of contract" with the state. The greater willingness to evade taxes has in turn privileged the non-traded sector at the expense of the traded sector since tax evasion is more easily carried out in the non-traded sector (medical and law services, car repairs, etc). The upshot is a vicious circle in which the efforts of government to collect more taxes by raising tax rates shifts resources to the sector more prone to tax evasion, thus, in the medium-term, worsening both the fiscal and the current account deficits.

The paper concludes with Section 6 in which we draw some inferences from our analysis of the past in order to identify issues which must be effectively dealt with if Greece is to avoid getting caught in a downward spiral which would make all the more difficult to "graduate" from the present crisis.

\section{A Bird's Eye View of the Evolution of Macroeconomic Aggregates}

In this section we give a brief overview of the main macroeconomic developments in Greece during the last four decades.

Following the end of the civil war in 1949, which started immediately after the official end of the Second World War, Greece started its reconstruction period in the 1950s. According to Maddison (1995), Greece had the lowest per-capita income among the EU15 countries in 1950. As is to be expected in such cases, the country experienced fast growth rates for three decades. Indeed, from 1950 to 1973, Greece was the fastest growing economy among the EU-15, and by 1973 its per capita GDP had risen above Ireland's and Portugal's. During the rest of the 1970s Greece's growth rate decelerated, but it was still the highest among the EU-15, and the second highest (to Japan) growth rate among the OECD countries. The evolution of per-capita GDP from 1960 to 2009 (at constant prices, with 2000 as the base year), is portrayed in Figure 1, whereas Figure 2 portrays GDP per capita in Greece relative to the EU15 and the average of Ireland, Italy, Portugal, and Spain (the peripheral 4). 


\section{Figure 1 here}

\section{Figure 2 here}

The long period of fast growth came to an abrupt end in the 1980s. During this decade, per capita GDP in Greece grew at only $0.3 \%$ per annum, compared with $2 \%$ for the EU15, and 2.1\% for the OECD. The start of this decade coincided with two events, i.e. Greece's accession to the EEC and the rise of the socialist party (PASOK) to power. Although there is some consensus among Greek economists that both of these events contributed to the precipitous decline in the growth rate, the relative importance of each factor remains a hotly disputed issue (the EEC for forcing an end to the pampered situation under which many Greek industries operated, PASOK for undertaking irresponsible wage and spending policies).

The anemic performance of the economy continued until 1993 (the 1990-1993 growth in per capita GDP was $-0.5 \%$ per annum), but improved for the rest the 1990s (Greece, EU15, and OECD having the same growth rate for 1994-1999 at 2.2\% pa.), and accelerated in the first decade of the new millennium (Greece: 3.2\%, Euro Area: 2.2\%, OECD: 2.5\% for 2000-2009 pa.) However, as it will become clear presently, the relatively fast growth of the last decade did not have solid foundations, but was based on an unsustainable public and private spending spree.

The accumulation of public debt through successive budget deficits is depicted in Figure 3 , for the period 1974-2009. ${ }^{2}$ For the moment we note the large deficits of the 1980s and early 1990s which took the debt-to-GDP ratio from $20 \%$ in 1975 to $100 \%$ in 1994 ; the fiscal consolidation of the 1994-2000 period as the government was focused on the goal of EMU participation; and the relaxation of the effort to fight fiscal profligacy after being admitted to the Eurozone.

\section{Figure 3 here}

If a picture is worth a thousand words, then the following two diagrams showing the evolution of (gross and net) national saving as a percentage of GDP from 1960 to 2009 take us a long way towards understanding the roots of the present fiscal (but, not only fiscal) crisis. The fast growth experienced by the Greek economy after 1950 (identified with the initial stages of its catch-up phase with the advanced OECD economies), was

\footnotetext{
${ }^{2}$ From 1953 to 1973 Greek governments were very prudent and, in most years, modest annual surpluses were recorded. This fiscal stance was partly a result of the fact that the country could not borrow internationally prior to 1966, when the settlement of the 1930s default was finally completed.
} 
associated with significant increases in both the net and gross saving rate until 1974. For the 35 years since 1974 there has been a steady decline in the saving rate, with the net saving rate dropping by about 25 percentage points (from $20 \%$ to minus $5 \%$ ) $^{3}$. This huge drop in the national saving rate has (since 1988) not been associated with a rise in government borrowing, but it is wholly attributable to the decline in the private sector's gross saving rate (from $27 \%$ in 1988 to $11 \%$ in 2008). In fact, as portrayed in Figure 4, it appears that the saving behaviour of the private sector vis-à-vis the (dis)saving behaviour of the government resembles what one would expect if the Ricardian hypothesis were true (i.e. efforts to decrease government borrowing would be offset by decreased saving of the private sector).

\section{Figure 4 here}

\section{Figure 5 here}

The decline in the national saving rate experienced by Greece parallels the declines observed in many other EU-15 countries, but in no other country has the decline been so pronounced. Figure 5 shows the net national saving rate for Greece, Ireland, Italy, Portugal, and Spain. Greece and Portugal are the only countries in the Eurozone for which the net national saving rate turned negative even before the onset of the global financial crisis in $2008^{4}$.

The upshot of the large decline in national saving for Greece has been a gradual widening of the current account deficit and the accumulation of foreign debt (Figure 6). During its period of fast growth from 1950 to 1973 (about 7\% per annum), Greece ran small current account deficits which were on average about $2 \%$ of GDP. These small current account deficits were made up of large deficits in the trade balance (about $7 \%$ on average) and significant surpluses (about $5 \%$ on average) on the income and transfers accounts, mainly reflecting remittances from Greek seamen and emigrants. Following the first oil crisis and up to Greece's accession to the EEC in 1981, there was a reduction in the growth rate (a still respectable 4\% per annum), and a marked improvement in the current account which turned into surplus - driven mainly by an improvement in the trade balance. From 1981 onwards, both the income and trade accounts started deteriorating (as emigrants started returning to the home country, and the gradual liberalization of trade took effect), but there was an improvement in the transfers balance (mainly transfers from the EU) which, as long as it lasted, prevented a large deterioration of the current account. This

\footnotetext{
${ }^{3}$ The difference between gross and net saving is the depreciation of capital (i.e., capital consumption). We also note that gross government saving is defined as the difference between gross government income and government consumption expenditure.

${ }^{4}$ Among the likely causes of the decline in the saving rate in Greece is the continuous decline of the share of agricultural employment (since farmers face greater income uncertainty than wage earners - especially government employees), and the gradual extension of unfunded pension benefits to a larger part of the population.
} 
came about after 2004, when the surplus in the (current) transfers account decreased, and the deficit in the income account deteriorated markedly ${ }^{5}$. The current account deficits incurred after 2004 have added almost 50 percentage points to the country's negative net foreign asset position as a proportion of GDP, which stood, according to Bank of Greece figures, at about 90\% of GDP by the end of 2009 .

\section{Figure 6 here}

\section{Debt and Deficit Decomposition}

In this section we decompose the well-known identity describing the accumulation of public debt along the lines suggested by Fortin (1996) and Kneebone and Leach (2001). Fortin's objective was to disentangle the relative importance of the following three factors to debt accumulation: (i) over-generous programme spending and lax tax policy (and administration) leading to a primary deficit even if the economy is operating at potential output; (ii) primary deficits arising as a result of output being below potential (due to the influence of automatic stabilizers), either because it has been subjected to unfavourable external shocks or because stabilization policies have been inadequate; (iii) the (real) interest rate exceeding the GDP growth rate, so that the debt ratio would rise even if programme spending and revenues are equal, as new debt would have to be issued to make the interest payments on the existing debt.

The government budget constraint implies that the stock of public debt at the end of period $t, B_{t}$, results from inherited debt at the end of period $t-1, B_{t-1}$, plus the budget deficit during period t, $D_{t}$ :

$$
B_{t}=D_{t}+B_{t-1}
$$

Since the budget deficit depends on interest payments (which may be considered not a choice variable of the fiscal authorities in period $t$ ), and thereby on the inherited level of debt $B_{t-1}$, interest payments can be separated from other expenditures, and the accumulation identity can be rewritten as:

$$
B_{t}=\left(1+r_{t}\right) B_{t-1}+P D_{t}
$$

where, the variable $P D$ is the primary deficit. To account for the effects of growth on the government's ability to borrow, after some simple manipulations we can approximate the evolution of government debt in terms of ratios to GDP (denoted by lowercase letters):

$$
b_{t}-b_{t-1}=\left(r_{t}-g_{t}\right) b_{t-1}+p d_{t}
$$

An implication of equation (2) is that in order for the debt ratio to be stabilized, the primary balance should be such that:

$$
p d_{t}=-\left(r_{t}-g_{t}\right) b_{t}
$$

\footnotetext{
${ }^{5}$ There was a also a deterioration in the merchandise (goods) trade balance, which was offset by the improvement in the balance on services, thus leaving the trade balance little affected on average during the pre-EMU 90s and the post-EMU era.
} 
This implies that in periods in which the real interest rate is higher than the growth of real GDP, the government must run a primary surplus ( $p d<0$ ). Moreover, it implies that the primary surplus consistent with a constant debt-to-GDP ratio increases with the initial debt ratio and the difference between the interest rate and the growth rate. Prudent governments should not be carried away by currently fortuitous combinations of high growth rates and low interest rates if they wish to avoid large increases in public debt, especially if the level of the debt ratio is high. In this vein, the dependence of the primary deficit on the state of the business cycle should not be ignored, as in periods of expansion (contraction) an unchanged government policy will result in lower (higher) spending (e.g., unemployment benefit payments) and higher (lower) tax revenue.

Using equation (2), we can rewrite the debt (ratio) accumulation identity as

$$
b_{t}-b_{t-1}=p d_{t}^{*}+\left(p d_{t}-p d_{t}^{*}\right)+\left(r_{t}-g_{t}\right) b_{t-1},
$$

where $p d_{t}^{*}$ stands for the primary deficit ratio when GDP is at its potential level. This equation makes clear the contribution to debt accumulation from operating at an output below full capacity. As a result, in equation (4) we have now that debt accumulation consists of three components. The first component is the structural component and measures the contribution of the primary deficit to debt accumulation if the economy is operating at full capacity. The second component is the cyclical component (this is the second term on the right hand side) and measures the contribution that the primary deficit makes to debt accumulation as a result of the economy operating below capacity. Finally, the third component, which has been called the rate component, measures the influence of the difference between the (real) interest rate and growth of GDP on the debt ratio.

In order to apply equation (4) in the Greek context we need to take into account various activities undertaken by governments which are not reported in the budget. This item appears under the term stock-flow adjustment, and it is the result of various factors. It can be due: to debt guarantees given by the government for the restructuring of publiclyowned enterprises and sub-national government entities; the variation in the valuation of debt denominated in foreign currencies as a result of exchange rate movements; debt assumptions by the government on behalf of third parties; military borrowing which affects the deficits only once military equipment has been delivered (until that moment the purchase is only recorded in the debt); the acquisitions of financial assets, such as capital injections to public enterprises; financial operations related to debt management such as the securitisation of future receipts, privatisation certificates, share-convertible bonds and exchangeable bonds; and privatisation proceeds (European Economy, 2004). Taking into account of the stock-flow adjustment term $\left(s f_{t}\right)$, the modified equation (4) reads:

$$
b_{t}-b_{t-1}=p d_{t}^{*}+\left(p d_{t}-p d_{t}^{*}\right)+\left(r_{t}-g_{t}\right) b_{t-1}+s f_{t}
$$

Before proceeding with the debt accumulation decomposition, we note that calculating $p d_{t}^{*}$ depends on the definition (and calculation) of potential output. This is crucial because it may affect the results of the debt decomposition. In general, there are two methods for calculating the full capacity output, which are called "trend GDP" and "sustainable GDP". Trend GDP takes two points in a time series where the GDP was 
highest and assumes that the trend between these two points represents the potential GDP of the economy; i.e. trend GDP could also be characterized as maximum possible GDP. This differs significantly from "sustainable GDP" or, put differently, the maximum sustainable GDP. The last one is calculated using a production function approach and uses measures of potential employment based on NAIRU estimates.

The Ameco database provides estimates for both measures of potential output, as well as estimates of the cyclically adjusted deficit for both of these measures. Since the results of using either measure of potential output do not affect to any significant degree the contribution of each factor to the evolution of debt, we will present results based on the sustainable GDP measure. (The results of the debt decomposition on the basis of trend GDP are available from the authors upon request.)

\section{Figure 7 here}

\section{Figure 8 here}

Figure 7 presents the annual decomposition of the debt accumulation, whereas Figure 8 presents the compound effect of the different components. Starting from 1990, when government debt was $72 \%$ of GDP, the debt ratio reached $113 \%$ at the end of 2009 . Figure 8 makes clear that the rise in the debt ratio by 41 percentage points from 1990 to 2009 can be wholly attributed to the stock-flow effect, which, in the absence of other forces, would have contributed 62 percentage points to the debt ratio. The joint, cumulative force of the other three components would have subtracted from the debt ratio 21 percentage points, of which the structural component contributed 12 points, the rate component 8 points, and the cyclical component just one percentage point.

Which government actions (both before and after 1991) were responsible for this huge contribution of stock-flow adjustments to the rise in the debt ratio? The Greek government had accumulated in the past (especially during the 1980s) large implicit liabilities in the form of loan guarantees to "restructured enterprises" which became quasi-public entities. From 1990 to 1993 the government took over these long-standing liabilities of these entities to the banking system - up to that point these liabilities were not recorded in government debt. ${ }^{6}$ These liabilities (known as "consolidation loans") amounted to 1.8 trillion drachmas (about 5.3 billion euro), and had by 1992 added 10 percentage points to the debt ratio. Large stock-flow adjustments were also recorded during the 1994-2000 period since the second phase of the EMU required a consolidation of government accounts, especially with the central bank. The government had three accounts with the central bank, which were overdrawn to the sum of 3.04 trillion drachmas (about 9 billion euro), all of which had to be transformed into formal debt by

\footnotetext{
${ }^{6}$ Large stock-flow adjustments took place in 1982 and in 1985 as well. These resulted from previous loans which the Bank of Greece extended to the government in order for the latter to make off-budget transfers to farmers.
} 
the end of 1993 so that Greece could enter the second phase of EMU (see Manessiotis and Reischauer, 2002 for more details). This action alone added another 16 percentage points to the debt ratio. In addition to these very large, debt-increasing, stock-flow adjustments, it is worth mentioning that during the consolidation period some (far smaller) debt-reducing adjustments were made. These involved the transfer of Social Security Fund's deposits from the central bank (where they were held in its own name) to the government's accounts, as well as the privatization revenue which were used to retire public debt. Further, debt-increasing stock-flow adjustments of similar nature, but of smaller significance, were recorded in subsequent years, thus pushing the total to 62 percentage points by the end of 2009 .

From Figure 7 we observe that from 1994 to 2000, the structural component contributed on average about 4 percentage points per annum to debt reduction. This process was reversed gradually from 2001 to 2009; during this period the structural component added on average about 2 percentage points per annum to the increase in the debt ratio. One may be justified in thinking that the efforts of Greek governments to reign in the accumulation of debt were relaxed after the country gained entry into the Eurozone. A more benign interpretation would take into account the steep rise in spending on infrastructure which the 2004 Athens Olympics necessitated and the recent global financial crisis. Nevertheless, although one could not blame the Greek governments for not predicting the global financial crisis, one would prefer that the governments had decided to match the extra spending for the Olympics with increased taxation - this would have been the prudent response to the vast increase in liabilities caused by the stock-flow adjustments.

We note that due to the low interest rate environment in which Greece was operating after EMU and until the onset of the global financial crisis, as well as the fast growth rates it experienced after 1994, the rate component did not contribute to debt accumulation (in fact, it subtracted 8 points). But suppose that the interest rate is larger than the growth rate during a period ( $r>g$ ). Would it be sensible to assume, in this case, that a responsible government should aim for programme spending to be equal to revenue (i.e., for a zero structural component)? Kneebone and Leach (2001) have suggested that if the period is long enough then the debt ratio could rise significantly even if the structural component is zero ${ }^{7}$. To think that sensible policymakers would be content to let debt pile up for decades, and that bond market participants would not penalize them for doing so, on the basis that "good times" (during which $g>r$ ) will eventually return, is absurd. For this reason, Kneebone and Leach have noted that “... the problem with Fortin's decomposition is that it separates the act of incurring a debt from the act of paying interest on that debt. The government is held responsible for its deficits, but someone else is held responsible for paying the interest on the debt issued to finance those deficits. Unfortunately, there is no one else, and the government should be expected to recognize that fact when it incurs debts." Their preferred decomposition, which redefines the

\footnotetext{
${ }^{7}$ They point out that the period after the Second World War can be split into two quarter-century subperiods; during the first sub-period the growth rate exceeded the interest rate for many OECD countries, whereas the opposite was true during the second sub-period.
} 
structural component to take into account that debt-burdened governments cannot spend as if they were not responsible for paying the interest on the outstanding debt, is:

$$
b_{t}-b_{t-1}=\left(p d_{t}^{*}-\left(g_{t}-r_{t}\right) b_{t-1}\right)+\left(p d_{t}-p d_{t}^{*}\right)+s f_{t}
$$

The redefined structural component implies that, if actual and potential output are equal, there is no tendency for the debt ratio to rise (in the absence of stock-flow adjustments) if $p d_{t}^{*}=\left(g_{t}-r_{t}\right) b_{t-1}$, rather than $p d_{t}^{*}=0$, which is the case in Fortin's definition.

How much would the conclusions we drew for Greece on the basis of Fortin's decomposition change if we adopted the decomposition proposed by Kneebone and Leach? Not much, since, as we have seen, the main culprit behind the rise in the debt ratio was the stock-flow component ${ }^{8}$. We portray the debt decomposition with the redefined structural component in Figure 9. Given that the cumulative impact of the rate component $\left(\left(g_{t}-r_{t}\right) b_{t-1}\right)$ to the reduction in the debt ratio was 8 percentage points between 1990 and 2009, the redefined structural component's contribution to reduction in the debt ratio is now estimated at $20(=12+8)$ percentage points. This allows us to credit Greek economic policy with some fiscal rectitude from 1990 to 2009 (although one can easily see from Figure 9 that economic policy was indeed responsible in some periods and irresponsible in others). However, the rectitude shown on average during this period can hardly be classified as prudent behaviour since the fortuitous occurrence of high growth and low interest rates for most of this period should not have been considered as a permanent fixture given the concurrent developments in the current account and the huge deterioration in the net foreign asset position. ${ }^{9}$

Figure 9 here

\section{A More Detailed Look at Government Revenue and Expenditures}

The previous section suggests that successive Greek governments have failed (with some exceptions) to reign in and reverse the process of debt accumulation. In order to gain a

\footnotetext{
${ }^{8}$ We note that the existence of the stock-flow adjustment term in the Greek case raises some further issues on whether the stock-flow adjustment term should be included in the redefined structural component. One may argue that, much like the interest payments on debt, governments should not ignore the likelihood that some of the contingent liabilities which they have assumed in the past will have to be explicitly honored at some time in the near future - we discuss this issue further in the following sections in relation to the unfunded obligations of the pension system in Greece.

9 According to van der Ploeg (2007), “...a prudent minister of finance deliberately underestimates future forecasts of national income and the tax base, and sets the tax rate(s) higher and the spending lower than without prudence. The benefit of such prudence is that as the inevitable windfall revenues materialize and the level of government debt and interest payments fall over time, welcome increases in government spending and/or reductions in tax rates can gradually be implemented without jeopardizing the ability of governments to act swiftly to stabilize the economy in the face of unexpected macroeconomic shocks". In the Greek context, the presence of a prudent minister of finance would also help since revenue shortfalls have been a common occurrence and the reality of cabinet decision making has spending ministers squabbling over who has to implement the spending cuts, with the end result being not conducive to efficient governance.
} 
better understanding of the reasons behind this failure we take, in this section, a closer look at the main determinants of government expenditures and revenue.

In what follows we focus on a broad measure of the public sector, referred to as General Government. This measure differs from the narrowest measure (i.e., Central Government) in that in addition to the standard public services (e.g., education, health, defense, law enforcement, the judicial system, tax collection), it includes the accounts of the social security system (close to 130, at the time of writing, primary and supplementary funds providing pension and health insurance); the activities of the sub-national and local authorities; the budgets of public entities such as universities and hospitals. The reason we concentrate on this measure of the public sector is that it was the focus of the Maastricht criteria as well as of the Stability and Growth Pact ${ }^{10}$.

The Greek government is highly centralized. Central government collected almost 67\% of revenues and accounted for about 55\% expenditures in 2007; the relevant figures for the OECD as a whole are 58\% and 43\%, respectively (OECD, 2009). Local governments represent a very small portion of total revenues and expenditures (Greece: $2.6 \%$ and $5.6 \%$, OECD: $17.6 \%$ and $32.2 \%$, respectively) and receive most of their revenues as grants from the central government (more than $90 \%$ of their funding). Social security funds account for over 30\% of revenues and almost 40\% of expenditures (OECD: $21.4 \%$ and $24.6 \%$, respectively).

\subsection{Government Spending and its Components}

Up until 1980, government spending in Greece was significantly smaller than the average for the countries which became the initial 12 countries of the Euro Area (EA-12). In 1970 , government spending as a proportion of GDP was $23 \%$ in Greece and $34 \%$ in EA12, whereas in 1980 the corresponding figures were 30\% for Greece and $43 \%$ in the EA12. ${ }^{11}$ After a huge expansion of the public sector in Greece in the 1980s, government spending as a proportion of GDP had by 1990 gone above that of the EA-12, the relevant figures being 49\% for Greece and 48\% for the EA-12 (OECD, 2006). Since the increase in spending was not accompanied by corresponding increases in government revenue, the explosion in public debt, as well as the prospect of EMU participation forced successive Greek governments in the 1990s to put the brakes on government spending. By 1999, government spending was down to $44 \%$ of GDP in Greece, compared with $48 \%$ in EA-

\footnotetext{
${ }^{10}$ A still broader measure of the public sector would include the accounts of many public enterprises, which are involved in public utilities, energy, infrastructure and transportation services, postal services, and various other activities. With the passage of time some of these enterprises have been partially of fully privatized. Many of the remaining ones require for their operation considerable annual subsidies and loan guarantees, which is one reason why successive governments have tried to privatize them. In any case, the continuously shifting boundary of this broader measure of the public sector (and the change in support from tax revenue it requires) implies that it may be wiser to express measures pertaining to the composition of government spending as proportions of GDP rather than total government spending.

${ }^{11}$ The low share of government spending until 1980 is noteworthy given Greece's large military spending, which has been on average $50 \%$ larger than what the government spends on education. The implications of this allocation of public spending for Greece’s long-run growth potential are beyond dispute.
} 
12. It appears that after gaining entry in the Eurozone, Greek policymakers stopped being as vigilant in their efforts to further curb government spending, and by 2008 (before the global crisis hit Greece), government spending stood at 48\%, climbing to 52\% of GDP in 2009. Of particular interest is the comparison in the evolution of government spending among the southern EU countries. Figure 10 shows that by 1997, government spending (as percentage of GDP) in Greece had surpassed the corresponding measures for the average of Ireland, Italy, Portugal, and Spain, whereas by 2008 it had matched the EU15 average.

\section{Figure 10 here}

The growth in government spending in Greece is largely accounted by the growth in social transfers, which rose from 8\% of GDP in 1970 to $21 \%$ of GDP in 2009), and in the compensation of public employees (from $8 \%$ in 1976 to $12.7 \%$ of GDP in 2009) ${ }^{12}$. Of particular interest is the fact that during this period government spending on gross fixed capital formation (excluding capital transfers received) remained practically unchanged, hovering around $3 \%$ of $\mathrm{GDP}^{13}$.

The growth in transfers (mainly to households) can be partly explained by the fact that as late as 1980 Greece spent only 11\% of its GDP on income transfers, whereas the average for the EU-15 was 17\%. The most important category among income transfers in Greece is pension benefits. This is the fastest growing category of social spending, and the biggest risk regarding the sustainability of public finances in Greece. ${ }^{14}$ Government spending on pension payments is expected to rise in Greece from 11.7\% of GDP in 2007 to $19.4 \%$ in 2035 (for the EU27 the rise is expected to be only 1.7 percentage points, taking it to $11.9 \%$ of GDP in 2035). Table 1 provides longer term projections for pension spending as well as for different categories of age-related expenditures. The sum of all other age-related government expenditures is expected to rise by only 1.4 percentage points until 2035 (in contrast to the 7.7 percentage points for pensions alone); this makes clear that Greek policymakers should ensure that a far-reaching reform of the pension system is instituted if the country is to avoid recurring fiscal crises like the one it is experiencing in 2010.

\footnotetext{
${ }^{12}$ For the earlier data see Ministry of National Economy (1998), whereas the recent data are from the Ameco database.

${ }^{13}$ Including capitals transfers received (EU funds) would raise this figure to about 6\% of GDP during the last decade (Ministry of National Economy, 2009).

${ }^{14}$ The Greek government in an effort to deal with the problem adopted some reforms in 2008 which are expected to bring some order to the chaotic system of social insurance. The main components of this reform were (i) to reduce the number of pension funds (from 133 to 5), whereas many other social insurance schemes which were based on agreements between firms and small groups of workers were consolidated under six supplementary (pension) schemes and two welfare schemes, (ii) increase the age at which some beneficiaries can retire on a full pension, (iii) to increase the age threshold for early retirement, (iv) to reduce the replacement rates of supplementary pension schemes, and (v) to improve the rules regarding maternity leave in order to encourage more women to enter the labour market (Athanasiou et al., 2009, and Zervou, 2009).
} 


\section{Table 1 here}

The large growth in general government spending on public employee compensation (from $8.3 \%$ of GDP in 1976, to $12.7 \%$ in 2009) ${ }^{15}$ is the result of considerable increases in both the numbers of (general) government employees and in their real wages, especially during the 1980s. While up to 2000, the Greek government was spending less (as a percentage of GDP) than the EA-12 average on wages and salaries, the inexorable rise in government spending on employee compensation is now higher than the EA-12 average. Between 1976 and 2009, the number of government employees increased by about 150\% (from 282 thousand to about 700 thousand ${ }^{16}$ ), while private sector employment during the same period increased by about 34\% (from 2.95 million to 3.96 million); thus, general government employment increased from 8.7\% of total employment in 1976 to about 15\% in 2009.

Real wages of civil servants got a very large boost in the 1980s; as an example, in 1982 alone, the average salary increases for the lowest-paid civil servants were increased by almost $100 \%$, with the increases in some cases being higher than $100 \%$. (In contrast, the minimum wage for private sector workers -which, at the time, was set by governmentcontrolled arbitration - was increased by 46\%. CPI inflation was 22\% in 1982 and 20\% in 1983.) These huge increases in the salaries of the lowest-paid civil servants were matched with significantly lower increases in the salaries of average earners and no pay increases for the highest earning categories. As a result, the central government's wage bill increased by 33\% in 1982. Following these pay increases, a partial indexation system was introduced, which gave workers wage increases at four-month intervals linked to the consumer price index. The portion of a worker's wage below 35,000 drachmas (about 103 Euro) per month was fully indexed, and components of the worker's pay above that amount were indexed at successively lower rates. The portion of wages above 80,000 drachmas per month was not indexed at all. This partial indexation formula was kept for a few years, subsequently was modified several times, before it was finally abolished in 1991. ${ }^{17}$

\footnotetext{
${ }^{15}$ These numbers are calculated from data in Ministry of National Economy (1998).

${ }^{16}$ The use of the word "about" is intentional. The Ministry of Finance at the moment (March 2010) has no precise idea of the total number of general government employees. This reflects mainly the unwillingness of various Ministries to reveal the number of civil servants employed in their core operations and in the public enterprises under their control. OECD (2009) reports that in 2005 public sector employment was $14.1 \%$ of the labour force; with a labour force of 4.85 million, this implies that public sector employment was about 684 thousand in 2005 . The number of employees in the wider public sector, including employees on short-term contracts, is estimated by some sources (Eurostat) to be just over 1 million, implying that its share in total employment is about 23\%. In April 2010, estimates from the Athens Chamber of Commerce and Industry raise the number of public sector employees to 1.1 million (inclusive of military personnel), whereas the Ministry of Interior recently announced that the number of public sector employees is 678 thousand. These large differences in numbers reflect, among other things, the fact that some public entities (e.g. Universities) employ a number of people out of own generated funds; these people are sometimes counted as public sector employees, but their salaries are not drawn out of the government's budget.

${ }^{17}$ The gradual recognition among policymakers of the significant disincentive effects of the resulting wage compression effects of such a "progressive" scheme of wage indexation was one factor behind its abandonment.
} 
The growth in public sector compensation costs was renewed in the 1990s under different guises. Wages in public enterprises have grown significantly faster than wages in other sectors. We can see from Figure 11 that the cumulative increase over the 1995-2006 period in (gross) nominal private sector wages (excluding the banking sector) was $82 \%$, whereas the cumulative increase in public sector wages was $118 \%$, and in publicly owned enterprises 157\% (see Fotoniata and Moutos, 2010). These large differentials in the evolution of pay not only make working for the private sector a less attractive option, but are also associated with higher tax rates and/or higher (relative) prices of publicly provided goods and services, since they hardly reflect differential increases in productivity between the public and private sectors.

\section{Figure 11 here}

The above described developments in public sector pay and employment, reflects the fact that public sector employment has remained a main tool through which political parties in Greece dispense favours to partisan voters, as well a "redistributive" tool in periods of high unemployment (see Demekas and Kontolemis, 2000). The relatively large size of employment in the public sector, and the desire of the two contending-for-thegovernment political parties in Greece to use appointments in the public sector to gain votes was one of the factors responsible for why the increases in public sector wages were consistently above those awarded in the private sector ${ }^{18}$.

\subsection{Sources of Government Funding}

The rise in government revenue followed, sometimes with considerable lag, the rise in government spending. Unlike government spending, whose fastest rise took place in the 1980s (its share in GDP rose by 18 percentage points), government revenue as a share of GDP rose by only 5 percentage points in the 1980s (from 27\% in 1980 to 32\% in 1990). The necessary adjustment in government revenue occurred in the 1990s, when its GDP share rose by 11 percentage points (from 32\% of GDP in 1990 to $43 \%$ in 2000). This brought Greece's tax burden 3 percentage points below the EU15 average (and above the average for Ireland, Italy, Portugal, and Spain), but by 2009 government receipts in Greece (at 37\% of GDP) had again fallen below the EU15 (which stood at 44.3\%) and the 4-country average (which stood at 39.2\%).

Figure 12 here

Direct taxes (including social security taxes) contributed the most to the rise in government revenue; whereas in 1976 they were 13\% of GDP and 47\% of total

\footnotetext{
${ }^{18}$ We note that the available evidence questions the wisdom of using government spending in Greece in order to control the business cycle. For example, Papageorgiou et al (2009) simulate a DSGE model calibrated to match Greek data and find that increases in public spending generate multipliers which are small (and can even turn negative) if distorting taxes are used to finance them.
} 
government revenue, by 2009 they had risen to 23\% of GDP and 59\% of government revenue. As a result, the significance of indirect taxes declined from $46 \%$ of government revenue in 1976 to 30\% in 2009. This reduction in the importance of indirect taxes was a result of two forces: first, the harmonization of indirect taxation in Greece with those of the (then) EEC in 1980 (the year prior to Greece's accession to the EEC) when many indirect taxes were cut or abolished ${ }^{19}$; second, the creation of the Single Market in 1993, when more indirect taxes were abolished. Figure 13 depicts the evolution of different sources of tax revenue.

\section{Figure 13 here}

Social security contributions, which provided $26 \%$ of government revenue in 1976, rose to represent $31 \%$ of revenue in 1985, and climbed to $38 \%$ in 2009 . This rise in the importance of social security contributions in tax revenue came about through large rises in statutory tax rates. In 1981, the rate for employer social security contributions stood at $18.75 \%$, whereas the employee rate at $10.25 \%$. By 2008 , these rates had risen to $28 \%$ for employers and $16 \%$ for employees. The relevant figures for the EU15 average in 2008 were $24 \%$ and $11.4 \%$, respectively (OECD, 2008).

The tax system in Greece has been and remains regressive relative to other EU countries. This is mainly because the income tax exhausts all of its progressivity at moderate income levels, e.g., in 2009 a proportional tax rate applied to all incomes above the $€ 60.000$ threshold. The taxation of interest income, which began in 1992, is another factor which contributes to making the tax system regressive. This is because this tax is not integrated with the income tax, and interest income is taxed at a constant rate which is independent of the taxpayer's other sources of income. In addition, many sources of income from investments in financial assets preferred by higher income groups have been either tax-free (i.e. repos) or are taxed at low rates. Finally, whereas in the past some indirect taxes on consumer durables were contributing to the progressivity of the tax system (i.e. excise tax on passenger cars, gasoline tax, road duties due to the fact that car ownership was concentrated among the better-off), these taxes have now become regressive as ownership of these goods has spread and there is no significant differentiation in the taxes applied between higher-priced and lower-priced items (Manessiotis and Reischauer, 2001).

If one were to observe the broad outlines of the Greek tax system in 2009, she may be tempted to conclude that it does not differ significantly from the tax system of other EU countries $^{20}$. However, the Greek tax system is replete with serious drawbacks. These have arisen as the tax system has been changing frequently in ad-hoc fashion to comply with EU regulations, to generate additional revenue, and to reverse (or, sometimes foster) real or perceived inequities of the tax system. These changes have been most of the times

\footnotetext{
${ }^{19}$ Following Greece's entry in the EEC in 1981, there was a large decrease of tariff revenue; whereas in 1974 tariff revenue contributed $7.5 \%$ to the total tax revenue, by 1982 the share of tariff revenue in total tax revenue had declined to $1.8 \%$, and by 1990 had declined to below $0.1 \%$.

${ }^{20}$ Nevertheless, the Greek tax system still retains its heavier reliance on indirect taxes.
} 
impervious to how the overall tax system serves the goals of vertical and horizontal equity, and on whether it promotes an efficient allocation of resources and fosters the country's international competitiveness.

Both the issues of equity and efficiency are adversely affected by the main issue bedeviling Greek public finances, i.e. tax evasion. This issue is particularly pertinent among those owning small businesses and the self-employed (from plumbers and electricians to medical doctors and lawyers) ${ }^{21}$. In the past, Greek governments have tried to deal with tax evasion by inferring an individual's income on the basis of "objective criteria". This method presumes that a minimum level of income is required for an individual to own assets or consumer durables of various sizes or value (e.g., houses, swimming pools, passenger cars, motor boats) and to pay for household services (e.g., maids, gardeners, drivers, tutors). An individual's tax obligations would then be calculated on the higher of their reported or "objectively calculated" income ${ }^{22}$. Various other methods have also been tried in the past in order to infer the income of selfemployed individuals (e.g., in the case of dentists an algorithm based on the years of practice, the geographical location of the surgery, the use of dental assistants, etc.).

Despite the shortcomings of these methods, it is worth noting that they resulted in higher tax obligations for many of the professional classes (e.g., medical doctors, dentists, lawyers, architects), which on average reported incomes below those earned by manufacturing workers. These methods were abandoned a few years ago in the expectation that the reduction in statutory tax rates would increase taxpayer compliance. However, the response of the professional classes was not the expected one since they continued to declare ridiculously low incomes ${ }^{23}$. As a result, the current Greek government, forced also by the threat of default, is bringing forward legislation which reinstates (and in some cases reinforces) the old "objective criteria" for the calculation of minimum taxable income. Although this is a move in the right direction, it remains uncertain whether tax administration officials will be willing to let the State have the tax revenue corresponding to the difference between the true incomes of the professional classes and the statutory minimum taxable income rather than being "persuaded" by these elite taxpayers to let the matter rest ${ }^{24}$.

\footnotetext{
${ }^{21}$ The share of the self-employed in total employment is very high in Greece; at 30\% it is the highest in the OECD, and about 18 percentage points higher than the EU15 average (Fotoniata and Moutos, 2010).

${ }^{22}$ In addition to income tax evasion, firms and workers (sometimes in amicable agreement with the firm, sometimes succumbing to take-it-or-leave-it threats by the firm) engage in considerable evasion of their social security contributions. The Inspectorate Service of the Social Insurance Foundation (IKA) estimated that employers in $10 \%$ of all firms inspected in 2008 failed to pay social contributions, while $27 \%$ of all workers remained unregistered (Matsaganis et al, 2010).

${ }^{23}$ For example, according to data released from the Ministry of National Economy, among the 151 medical doctors practicing in the most lucrative (for medical professionals) area of Athens, more than $40 \%$ of them reported annual, before-tax, incomes less than $€ 20.000$ in 2008. This figure is lower than the corresponding average for wage earners.

${ }^{24}$ Tatsos (2001) presents evidence according to which high earners in Greece were more inclined to noncompliance. This may not only reflect the possibility that it is inherently more difficult to find the true incomes of the self-employed, but it may also reflect their ability to offer higher bribes, or to draw on their high social connections in order to "discipline" (e.g. through unfavourable postings) any forthright tax officials who wanted to do their duty.
} 
In addition to the scandalously large rates of income tax evasion ${ }^{25}$, Greece faces very high rates of payroll tax evasion. As is to be expected in such cases, the estimates vary widely. Studies conducted by the Social Insurance Foundation (IKA) estimate that payroll tax evasion has increased through the years; the early 1990s estimates were hovering around $13 \%$ of revenues, whereas more recent estimates raise this figure from about $16 \%$ in 2003, to 20\% in 2005 (POPOKP, 2005). The numbers of persons who were either forced or chose to remain uninsured was estimated to be close to $23 \%$ of total employment, with the immigrants being 4 times more likely to be uninsured than the indigenous population. The steady increase of the share of immigrants in the labour force may thus be a contributing factor to the rise in payroll tax evasion. Another reason behind the high evasion rates is that the system was badly designed; for example, (private sector) workers insured with IKA, receive practically the same (post-tax-and-benefits) pension independently of whether one was paying contributions for 15 or 30 years, and whether one was earning (and contributing) twice as much as the other ${ }^{26}$. The incentives for collusion between employer and employee in order to minimize their social security contributions are obvious in such a case ${ }^{27}$.

A fundamental issue bedevilling the Greek tax system is that problems, policies and solutions are recycled, with damaging effects on long-term coherence. On the face of it, successive Greek governments have tried to implement reforms aimed at increasing the efficiency of tax collection, mainly through efforts to curb tax evasion. For example, from 2004 to 2007 new measures were instituted with the aim of reducing tax evasion. The most important of these measures were: (i) the imposition of VAT on new buildings (aimed at reducing the incidence of informal activity in construction activities), and (ii) the upgrading of the information technology used for the cross-checking of tax data and the restructuring of audit services. In addition, cuts in personal income taxes and measures to broaden the tax base (through the imposition of a $10 \%$ tax on dividends and capital gains) and to simplify the tax system (through a unique property holding tax) were introduced. Yet, much as the mythical Atlas, the monster of tax evasion, has not shrugged from the weight of these measures. A reason for that is the measures are most of the time piecemeal and do not take into account all other pieces of existing legislation ${ }^{28}$. Another

\footnotetext{
${ }^{25}$ Schneider and Enste (2000) and Schneider (2006) estimate the size of the shadow economy in Greece to be the largest (as a proportion of GDP) among 21 OECD countries. Their estimates hover between 25 and 30 percent of GDP. Tatsos (2001) argues that tax evasion may have been as high as 15\% of GDP in 1997.

${ }^{26}$ For example, somebody earning $€ 450$ per month and contributing for 15 years, would have received (in 2005) just €16 less per month than somebody earning $€ 900$ per month and contributing for 30 years, after the Social Solidarity Subsidy (EKAS) was taken into account.

${ }^{27}$ We note that the above figures do not take into account the huge arrears in the payments of social security contributions by employers (see, Experts Report on Social Insurance, 2010). Sometimes "politically influential" employers (e.g., owners of newspapers or TV stations) are allowed to carry forward their obligations under the implicit understanding that they will never have to pay as long as they provide a friendly (or, not an openly hostile) forum for the political party in power. Beyond outright corruption, threats of bankruptcy and the attendant employment losses seem also to have persuaded some officials to turn a blind eye to such infringements.

28 The Commission for Reforming the Tax System (2002) produced a report (known as the "Georgakopoulos Report") with a comprehensive set of measures which should be undertaken in order to increase both the allocation and efficiency effects of the tax system as well as increase its transparency and
} 
reason is that recurring tax amnesties have eroded the credibility of the system by providing incentives to taxpayers to delay and eventually evade the payment of taxes. A further incentive for tax-evading behaviour is provided by the existence of deadlines that permit taxpayers to be absolved of their tax obligations if the state has not managed to collect the owed taxes in time ${ }^{29}$. In 2007 alone, around $€ 3.5$ billion (about $1.5 \%$ of GDP) in taxes were written off, mainly to lapses in time for the collection of the tax revenue (State Audit Report, 2008).

\section{Some Salient Features of Greek Political Economy}

A natural question to ask at this point is what features of the Greek state, economy, and society are conducive to the "imprudent" behaviour described in previous sections? In other words, how did the amalgamation of private and state interests gradually lead to the current state of affairs?

Greece's strong macroeconomic performance from 1953 to 1974 was to a large extent underpinned by the April 1953 devaluation of the drachma (by 50\% vis-à-vis the US dollar). This period coincided with monetary stability (the inflation rate for Greece in the 1960s was 2\% per annum), which was interrupted by the collapse of the Bretton Woods system and the first oil crisis. The restoration of democracy in 1974 released a pent-up demand for increased consumption, which lead to declining rates of capital accumulation and economic growth. At the same time, the dismantling of repressive political mechanisms meant that governments had to rely on social and economic policy measures in order to garner political support. The growing societal demands, along with the willingness of the then conservative governments to appease an electorate which was all too eager to resume the radicalism of the 1960s, led to a transfer of systemic power from the state to society, or rather, from a moderately-effective state bureaucracy (the semblance of a strong state in the Weberian tradition) to groups which claimed to better represent society's interests (Pagoulatos, 2003).

The growing influence of societal groups (from trade unions to employer associations) in combination with the excessive politicization and weakening of the autonomy of the bureaucratic apparatus after 1974 (and especially after 1981) paved the way for the gradual transformation of the Greek state administration from an almost "developmental state" to an "intermediate state" (Evans, 1995) ${ }^{30}$. This transformation was effected by the greater penetration of the state bureaucracy by the two political parties (New Democracy and PASOK) which alternated in government since 1974. The objective of both parties was to capture all aspects of public administration by transforming the older

\footnotetext{
taxpayer compliance. The report was widely praised in government circles, but as is usual in such cases in Greece, and despite the fact that it was a government-sponsored report, its recommendations were largely ignored in favour of piecemeal legislation.

${ }^{29}$ As much as one may want to attribute such losses in tax revenue to the inefficiency of public administration, it is hard to avoid the conclusion that outright collusion between the tax authorities and some "politically-connected" taxpayers does not take place.

${ }^{30}$ The term "developmental state" is meant to capture the benevolent power exercised by an autonomous elite state bureaucracy, which has the ability and the foresight to channel funds to productivity and competitiveness enhancing activities (Johnson, 1982).
} 
individualistic (or family-based) system of patron-client relationships to one dependent on favours bestowed on party members by the party machine (Charalambis, 1989). The absence of a strong and confident bureaucracy in Greece allowed the political parties to have an overwhelming influence on personnel choice and promotion to potentially lucrative posts. The capture of the public administration by the political parties was cemented by the fragmentation of the unions representing public-sector workers along party-political lines. In effect, this meant that able civil servants had to "take sides" and "declare their allegiance" with a particular political party if they wanted to avoid being left behind in their careers while other less able employees were promoted. As a result, many civil servants were using great discretion in applying the rule of law: "politicallyconnected" citizens were receiving favourable treatment (e.g. land use and public health violations were ignored, tax evasion was not sanctioned, etc) whereas the full weight of the bureaucratic complexity of rules and regulations was applied to "unimportant" citizens. The latter, fully cognizant of the formal power of the bureaucracy to invent obstacles to the timely settling of the issues at hand, were often induced to offer bribes for the timely (but not unlawful) clearing of the matter ${ }^{31}$. The continuous sharing of experiences among citizens regarding their dealings with the state bureaucracy, along with the increasingly apparent indifference of the state apparatus (including the legal system) to the unlawful conduct of many civil servants, led, albeit grudgingly, to the "normalization" of this situation, and to a reduction in the apparently Quixotic efforts of some citizens to officially report on such occurrences. Moreover, gradually "bad behaviour" was driving out "good behaviour", since many civil servants who were not willing to submit to the party apparatchiks (usually colleagues who were trade union officials), were marginalized.

Political patronage was effective not only in distributing favours to civil servants and aiding in the unlawful acts of private citizens; it was also detrimental in influencing the work ethos and professionalism of public sector employees (tax officials, judges, medical doctors, teachers and professors included as well). ${ }^{32}$ The case of the National Statistical Service of Greece (ESYE) is particularly apt in this respect. ${ }^{33}$ The history of ESYE reveals that its chief officer (General Secretary) was replaced when a new party was elected to power. The main objective behind this practice was to control the flow of information; in this respect, the personal or political allegiance of the chief officer was the most crucial factor for the appointment. However, given the recent allegations against the credibility of the data provided by ESYE, one wonders why the choice of the chief officer by the party in power would be enough to stop leaks to journalists by upstanding employees or of employees with different political affiliations in cases that the accuracy of the data was in question ${ }^{34}$. Among possible answers is that in environments in which

\footnotetext{
31 According to the Ombudsman of the Greek Republic, civil servants enjoy too great a discretion in regard to the texts they have to apply, or else the procedures are so lacking in transparency and so open to interpretation that they encourage corruption among the public who want their administrative problems settled in a reasonable time (Greek Ombudsman, 2004).

${ }^{32}$ Comparative analysis of public sector efficiency suggests that Greece could have achieved the same level of public sector output by using only $73 \%$ of the inputs it is using (Afonso et al, 2003).

${ }^{33}$ We wish to thank Alfons Weichenrieder for prompting us to examine this case.

${ }^{34}$ In fact, in 2003, a high-ranking employee refused to sign the release of some data. Although the case was reported in the press, no further details are available.
} 
the ethos and professionalism of employees are undermined by the open exercise of favouritism, the narrowly-defined interest of the employees (i.e. their incomes) takes precedence. This was aptly illustrated in 2003 when the Minister of Finance decided to grant ESYE independence from the Ministry. This would have meant that ESYE's employees would receive a lower income since some benefits received by the Ministry of Finance employees would no longer be received by them. After a two-month strike in 2003, the employees managed to "persuade" the then Minister of Finance to remain under the mantle of the Ministry. Following the change in government in 2004, they also received a significant increase in their incomes after the favourable intervention that the newly appointed General Secretary made, on their behalf, to the new Finance Minister. The significance of the Minister's decision was not lost on ESYE employees; they understood that if they failed to "co-operate" by insisting on independent checks on the data sent to them by the General Accounting Office, the Minister of Finance may well decide to turn ESYE into an independent authority with the attendant loss of incomes. We note that the existence of some employees for whom the execution of their sworn duty carries more weight than their level of income may not be enough to allow for evidence-based leakages to the press regarding the accuracy of the reported data. Such leakages can be prevented by (i) allowing only the "trustworthy" to have access to the totality of the data, and (ii) by cultivating a culture in which the interests of the many employees should take precedence over issues of personal integrity (public sector trade unions are particularly adept at this), thus threatening to socially ostracize potential whistleblowers (in addition, to negative repercussions for their career).

The gradual weakening of state power did not go unnoticed by the private sector. Sometimes forced by the blatant extortionary demands of civil servants, sometimes taking the first step in nurturing a mutually beneficial relationship with the civil servants, private interests have captured the day-to-day functioning of public administration, and have distorted the implementation of economic policy. However, in case anyone thought that the problems of the Greek state arise mostly from the existence of unscrupulous civil servants who fail to implement the decisions of benevolent policymakers, two examples of irresponsible policy actions (the second one in the middle of the brewing fiscal crisis) will suffice: in September 2003 and in April 2009 the government decided to cut taxes on automobiles, the tax cut in both cases resulting in a small drop in the price of low-priced models (less than 2\%), and a large drop in the prices of expensive models (more than 15\%). Given that Greece had a large debt/GDP ratio and was running considerable budget deficits despite fast growth (in 2003), we have to concede defeat in finding an explanation in favour of the economic efficiency or the social justice of these tax expenditures.

Allowing private interests to shape policymaking and their implementation may have helped some groups, but the aggregate effect of public sector inefficacy in policy implementation and in the provision of public services had deleterious effects on the dynamism and competitiveness of the private sector ${ }^{35}$. One may appreciate the adverse

35 Angelopoulos et al. (2009) provide some estimates of the social costs of rent seeking for many European countries. They find that Greece exhibits the highest rent extraction and rent seeking, with about $53 \%$ of tax revenue extracted by rent seekers. 
effects of the failure of the state apparatus to provide an adequate amount and quality of public services as well as to raise the necessary tax revenue in an efficient manner, by considering the following interactions between tax evasion, the provision of public services, and the competitiveness of the economy.

Although it is easy to understand the political economy behind the labyrinthine structure of the Greek tax system (i.e. special interest politics, with the interest of tax officials playing a large role, since its simplification would reduce their ability to extract bribes), its consequences are not equally obvious. This is because tax evasion, among other things, affects (i) the specialization of the economy between traded and non-traded sectors, and (ii) the economy-wide productivity level.

In order to understand how these effects come about, we need to make only one assumption, namely, that tax evasion is more prevalent in non-traded goods (medical and law services, car repairs, etc) than on traded goods. The realism of this assumption can be appreciated by realizing that, as is well known in the literature (e.g. Bernard and Jensen, 1995), exporting firms tend to be larger than firms selling only in the home market, and to be more productive as well. It is also well known (e.g. de Paula and Scheinkman, 2009), that exporting firms usually transact with other formal-sector firms, like financial intermediaries, and also need the appropriate documentation to export.

The implication of the above is that the effective after-tax relative price of the traded sector is smaller than what one would surmise by looking simply at the prices of the two sectors, thus attracting fewer resources in the traded sector. Fighting tax evasion results in a rise in the effective relative price of the traded sector, reduces the attractiveness of nontraded sector activities, and makes the economy more export-oriented. In addition, since exporting, and, in general, formal-sector firms are more productive than informal sector firms (see, Rausch, 1991), the correction in the existing distortion regarding resource allocation which the reduction in tax evasion would bring about, would raise the economy’s overall productivity and thus contribute to higher living standards.

In addition to its effects on the allocation of economic activity, the economy's openness and its level of productivity, the gradual deterioration in the efficacy of public administration had other, even more serious, consequences on economic outcomes. Since 1975, tax revenue, as a proportion of GDP, have increased by more than $60 \%$ (from about $25 \%$ to about $40 \%)^{36}$. However, this rise in the tax burden has not been balanced by an equivalent rise in the provision of public services. In fact, in some cases, there has been a significant rise in spending on privately-provided services which complement the worsening quality of publicly-provided ones. A prominent example of such expenditures results from the numerus clausus arrangements regarding entry to tertiary education in Greece, and the attendant competitive national examinations. Although there has been a large rise in the proportion of students admitted to tertiary education during the last 35

\footnotetext{
${ }^{36}$ It bears noting that this rise in the tax burden in Greece was not felt equally by all; it is likely that the rise in the tax burden of employees has been significantly higher since they can not evade taxes on their formal sector jobs, although they can do so by moonlighting.
} 
years (from about 15\% of the high-school graduates in 1974 to about $40 \%$ in 2008), thus lessening the competition for the available places, private spending on crammer schools preparing students for the national exams has increased; Kanellopoulos et al. (2003) estimate that the share of education expenditures in household budgets (mainly on crammer schools and private tutors) rose from $2.15 \%$ in 1974 to $4.41 \%$ in 1999 . Recent studies (KANEP, 2009) estimate that in 2005 this figure had risen to 5.09\% of household budgets. (As a proportion of household spending for families with children in secondary school this can reach to more than $20 \%$ of household income, see Psacharopoulos and Papakonstantinou, 2005.) This rise in spending on crammer schools and on hiring of private tutors $^{37}$ reflects the widespread perception among parents (and teachers) of a continuing deterioration in the quality of publicly-provided education ${ }^{38}$.

The same inadequacies regarding the provision of public services have also been documented with respect to health care, in which case many attempts at efficiency-and equity-enhancing reforms have been prevented by powerful elites (e.g., professors in medical schools) - for details see Mossialos and Allin (2005), and Mossialos et al (2005). The deterioration in the effectiveness of health care provision in Greece has been documented by Data Envelopment Analysis which links health outcomes to the resources allocated to health care, as well as other relevant variables. OECD (2009b) estimates that between 1990 and 2006 the relative efficiency of Greece's health care system eroded significantly, and that this decline in performance stems more from a decline in technical and organizational efficiency rather than from higher input prices.

The upshot of these has been that the drop in disposable incomes has not been counterbalanced by an equivalent reduction in spending needs due to adequate provision of public services. Private sector workers have been particularly hit by these developments, since their wages have not been increasing as fast as public sector wages (see, Figure 11). These large differentials in the evolution of pay not only made working for the private sector a less attractive option, but are also associated with higher tax rates and/or higher (relative) prices of publicly provided goods and services, since they hardly reflect differential increases in productivity between the public and private sectors.

In consequence, private sector unions, which cared about the value of real wages (net of taxes, but inclusive of public services), have been trying to extract from the employers nominal wage increases above the sum of expected inflation and productivity gains. Indeed, a common claim which the leaders of the General Confederation of Greek Workers brought during the bi-annual rounds of wage negotiations was that the government-announced figures for inflation (past and expected) were significantly below

\footnotetext{
${ }^{37}$ Lest a reader think otherwise, the incomes of private tutors go largely unreported.

${ }^{38}$ The drop in the quality of public education has been reinforced by the rising importance of crammer schools and private tutors. In many cases, the private tutors are also (illegally) full-time public school teachers. Since their income as private tutors depends on their performance as such, while their income as public school teachers is independent of the quality of their teaching at the public school (which takes place in the morning), they usually devote less energy to their morning duties as they try to preserve their enthusiasm for their private classes later in the day. As a result, students also tend to pay less attention to their less energetic morning teachers, and try to direct their effort to learning more from (sometimes the same) private tutors and crammer school teachers.
} 
the true rises in the cost of living due to the growing need to supplement the declining quality of public services by privately- provided ones. The upshot of this has been a wage-price spiral which resulted in rises in nominal wage and price inflation (since firms were able to keep real wages from rising above productivity gains ${ }^{39}$ ), whose detrimental effect on international competitiveness was forcing continuous devaluations of the drachma. Following Greece's entry into EMU, the inflationary pressures subsided, but a positive inflation (and unit labour cost) differential remained vis-à-vis the other eurozone countries, resulting in real exchange rate appreciation, which contributed to the widening of the trade and current account deficits and the fast rise of net foreign debt to about $90 \%$ of GDP in the first quarter of 2010.

In addition to the continuous loss of competitiveness due to wage increases for the reasons described earlier, the private sector in Greece had to navigate through a haphazard bureaucratic environment which, although formally defended as an attempt of the state to promote the public, as opposed to private, interest, it created a rent-seeking apparatus which allowed both inefficient firms to remain in operation and stifled the development of new enterprises ${ }^{40}$. Given that public sector employment has remained a main tool through which political parties in Greece dispense favours to partisan voters, as well a "redistributive" tool in periods of high unemployment, it is unsurprising that successive governments in Greece have responded to the lack of job creation by the private sector through an expansion of public employment. The loop thus closed; i.e. increases in public employment (without equivalent increases in publicly provided goods and services), result in increased tax rates and wage demands, a weakening of private sector performance and employment opportunities, with the "nanny" state intervening to alleviate what it may have caused in the first place, thus providing a new impetus to the vicious circle. The current multifaceted crisis of the Greek economy and society may force an end to this vicious circle, if the loop's causality is correctly diagnosed and there is the attendant political capital to enforce the necessary reforms ${ }^{41}$.

\section{Conclusion}

The Greek economy entered the second phase of EMU with both a large public debt and a large budget deficit, and went through a reduction of more than 9 percentage points (of GDP) in its budget deficit between 1993 and 2000 in order to be admitted to the euro area. Unfortunately, these efforts were to a large extent abandoned in the subsequent years. This was because in the pre-EMU accession phase, the threat of exclusion acted

\footnotetext{
${ }^{39}$ From 1995 to 2008, the rise in both the minimum and the average wage has not kept up with increases in business sector productivity (Fotoniata and Moutos, 2010).

${ }^{40}$ According to Pedersini (2007), Greece has the largest share of micro enterprises (i.e. those with less than 10 employees) among the EU15 countries. The preponderance of these enterprises - which mainly cater for the domestic market - testifies to the lack of dynamism in the private sector.

${ }^{41}$ An alternative interpretation of the loop has causality running from an inefficient private sector whose apparent success in the past relied on the heavy protection (cum subsidies) accorded to Greek industry. This came to an end after Greece joined the EEC in 1981, which "forced" the Greek state to assume the role of "employer of last resort" (see Tsakalotos, 1998, 2005, for a variant of this argument). Although we think that this interpretation has some merits, we note that in 1981 there was also a "regime" change in Greece with the rise to power of a Socialist government and the intensification of the politicization of the bureaucracy, thus making it very hard to disentangle the influence of each factor.
} 
like a hard budget constraint which forced the Greek government to redress its fiscal imbalances. In contrast to the, output-driven, "hard-conditionality" of the pre-accession period, the post-EMU accession period was characterized by the "soft-conditionality" of the Stability and Growth Pact, which allowed Greece (even more than other governments) to breach both the letter and the spirit of the Pact (von Hagen, 2005). Of more concern for the current developments is the fact that the Maastricht criteria stated numerical targets without paying any attention to the modality or quality of fiscal adjustment.

There seems to be a consensus in the literature that the quality of fiscal adjustment depends on the way fiscal consolidations are achieved. In particular, it has been argued that fiscal adjustments which rely too heavily on increasing tax revenue rather than on cutting government spending are less likely to be successful and sustainable (e.g., Alesina and Ardagna, 1998, Perotti et al., 1998, von Hagen and Strauch, 2001). A reason for this is that for the consolidation to be successful it must deal forcefully not only with politically-sensitive spending items, such as transfers and public sector wages, but it must also stop the hidden (legal or otherwise) subsidies given to inefficient, but politicallyconnected firms, which stifle the creation of new and productive ones ${ }^{42}$. Stamping out on these cancerous "collaborations" between private interests and the (formally) appointed custodians of the public interest is the only way to break up the vicious circle in which many firms survive due to government kickbacks while at the same time the government acts as the "employer of last resort" thus both shouldering the obligations of inefficient firms and burdening both workers and efficient firms with unnecessarily high tax rates and excessive red tape.

The Greek experience confirms the temporary nature of adjustments which rely too heavily on tax increases. From 1993 to 2000, the share of tax revenue in GDP increased by about 8 percentage points whereas the share of government spending remained intact. The recent (May 2010) case of a former Transport Minister who admitted to accepting payments from the Greek branch of a multinational firm which was a large supplier to the Greek government - he described these payments in testimony as "pre-election donations"- along with many other cases currently under investigation for corruption, provide further evidence that in countries in which outright corruption and tax evasion are endemic the beneficiaries of these practices will use their political power to minimize the reduction in public spending (their main source of pilfering) and shift the burden of budget consolidation to increases in taxation (which they are adept at avoiding or evading). Our analysis has shown why such a political strategy can be a winner: it allows for the development of a heterogeneous coalition of voters. In addition to the corrupt "big fish", these are: the many (usually low-income, low-skill) households for whom the government is the employer of last resort, the self employed (among whom the incidence of tax evasion is high, but whose incomes depend on government contacts), and the farmers (whose survival depends on subsidies and are not heavily taxed), not to mention many corrupt public sector employees whose "discretionary" income depends on the size of government.

\footnotetext{
${ }^{42}$ Very often in Greece, the hidden subsidies take the form of tax expenditures in the form of very low tax rates (or tax exemptions) for certain politically powerful sectors.
} 
During the soft conditionality of the EMU period, government spending renewed its upward path whereas tax revenue (as shares of GDP) started declining. The lack of prudence (or foresight) displayed by the Greek governments since 2000, is symptomatic not only of the low interest rates that EMU entry availed to Greece, but also of the deep entanglement between political and economic power that continues to engulf Greece. Powerful elites, "aided" by the cheap access to funds which EMU seemed to provide, have managed to maintain their ability to raid on state coffers, to hamper the adequate provision of public services at the benefit of private providers, and to forestall innovating (but threatening to their interests) firms from coming into existence. These elites have managed to legitimize their position by permitting weaker groups to also benefit by a system of soft budget constraints (or, outright anomie) in which the pilfering of public resources remains largely unpunished. As a result, Greece has reached a frightening homeostasis which can be broken only if the main beneficiaries of the current politicoeconomic equilibrium lose their undue privileges. The hard conditionality imposed on Greece in May 2010 by the EU/ECB/IMF will not succeed in averting an eventual default (through the usual austerity measures) unless it acts as the outside force which succeeds in reducing the power of the elites. In this respect, we note that although the elites, and most of the Greek population, are, at the moment, in favour of the bailout (though, the latter, not of the austerity measures), it would not surprise us if the elites switched in favour of default later, in case they thought that their power to shape policy in Greece could be compromised by policy proposals of the outside actors which went beyond the usual austerity measures. 


\section{References}

Afonso, A., Schuknecht, L., and Tanzi, V. (2003), "Public Sector Efficiency: An International Comparison”, ECB Working Paper No. 242, European Central Bank, Frankfurt.

Alesina, A., and Ardagna, S. (1998), “Tales of Fiscal Adjustments”, Economic Policy 13(27), October, pp. 489-545.

Angelopoulos, K., Philippopoulos, A., and Vassilatos, V. (2009), “The social cost of rent seeking in Europe”, European Journal of Political Economy, 25, pp. 280-299.

Athanasiou, L., Zervou, F., and Kotsi, A. (2009), Economic and Demographic Sustainability of the Social Insurance System, Report No 57, KEPE, Athens (in Greek).

Bernard, A. B., and Jensen, J.B. (1995), "Exporters, Jobs, and Wages in U.S. Manufacturing: 1976-87”, Brookings Papers on Economic Activity: Microeconomics, Volume 1995 (1995), pp. 67-112.

Charalambis, D. (1989), Clientilistic Linkages and Populism, Exantas, Athens, (in Greek).

Commission for Reforming the Tax System (2002), Report on Reforming the Tax System, Ministry of National Economy, Athens (in Greek).

Demekas, D., and Kontolemis, Z. (2000), “Government Employment and Wages and Labour Market Performance,” Oxford Bulletin of Economics and Statistics, Vol. 62, No. 3, pp. 391-415.

European Economy (2004), Public Finances in the EU-2004, European Commission, Brussels.

Evans, P. (1995), Embedded Autonomy: States and Industrial Transformation, Princeton University Press, Princeton, NJ.

Experts Report on Social Insurance (2010), Ministry of Employment and Social Protection, http://www.ypakp.gr/uploads/docs/3723.pdf (in Greek).

Fortin, P. (1996), “The Canadian Fiscal Problem: The Macroeconomic Connection,” in P. Fortin and L. Osberg (eds.), Unnecessary Debts, Lorimer: Toronto.

Fotoniata, E., and Moutos. T. (2010), "Greece: Neglect and Resurgence of Minimum Wage Policy”, in D. Vaughan-Whitehead (ed.), The Minimum Wage Revisited in the Enlarged EU, Edward Elgar and International Labour Office: Geneva.

Greek Ombudsman (2004), Annual Report 2004, http://www.synigoros.gr/annual04/04apologismos-skp.pdf.

Johnson, C. (1982), MITI and the Japanese Miracle, Stanford University Press, Stanford, CA.

Kanellopoulos, K., Kousoulakos, I., and Rapanos B. (1995), Shadow economy and tax evasion: estimates and economic implications, Center of Planning and Economic Research, Athens (in Greek). 
Kanellopoulos, C.N., Mitrakos T., and Mavromaras, K.G. (2003), Education and labour market, Center of Planning and Economic Research, Athens (in Greek).

KANEP-GSEE (2009), Main Figures of Greek Education, Center for the Development of Education Policy, General Confederation of Greek Workers, available at www.kanep-gsee.gr .

Kneebone, R., and Leach, J. (2001), “The Accumulation of Public Debt in Canada”, Canadian Public Policy, Vol. XXVII, no. 3, pp. 297-312.

Maddison, A. (1995), Monitoring the World Economy, 1820-1992. Paris: OECD Development Studies.

Manessiotis, V., and Reischauer, R. (2001), “Greek Fiscal and Budget Policy and EMU”, in R. Bryant, N. Garganas, and G. Tavlas (eds.), Greece's Economic Performance and Prospects, Bank of Greece and the Brookings Institution: Athens and Washington, D.C.

Matsaganis, M., Benedek, D., Flevotomou, M., Lelkes, O., Mantovani, D., and Nienadowska, S. (2010), Distributional Implications of Income Tax Evasion in Greece, Hungary and Italy, MPRA Paper No. 21465, Munich Personal RePEc Archive, Munich.

Mavrogordatos, G. (2001), Pressure Groups and Democracy, Patakis, Athens (in Greek).

Ministry of National Economy (1998), The Greek Economy 1960-1977: Long-Run Macroeconomic Time Series, Athens.

Mossialos, E., and Allin, S. (2005), 'Interest Groups and Health System Reform in Greece', West European Politics, 28: 2, pp. 420-444.

Mossialos, E., Allin, S., and Davaki, K. (2005), Analysing the Greek health system: A tale of fragmentation and inertia, Health Economics, 14, pp. S151-S168.

Mouzelis, N. (1978), Modern Greece: Facets of Underdevelopment, Macmillan, London.

OECD (2008), Taxing Wages 2006-2007, OECD, Paris.

OECD (2009a), Government at a Glance, OECD, Paris.

OECD (2009b), OECD Economic Surveys: Greece, OECD, Paris.

Pagoulatos, G. (2002), Greece, the European Union, and the 2003 Presidency, Research and European Issues $\mathrm{N}^{\circ} 2$, Notre Europe.

Pagoulatos, G. (2003), Greece's New Political Economy: State, Finance and Growth from Postwar to EMU, Palgrave Macmillan, New York, NY.

Papageorgiou, D., Philippopoulos, A., and Vassilatos, V. (2009), A toolkit for the study of fiscal policy in Greece, mimeo, AUEB, Athens.

de Paula, A., and Scheinkman, J. (2009), “The Informal Sector”, PIER Working Paper 08-018, Penn Institute for Economic Research, Philadelphia 
Pedersini, R. (2007), "Industrial Relations in the EU, Japan, US and other global economies, 2005-2006”, European Foundation for the Improvement of Living and Working Conditions, Dublin.

Perotti, R., Strauch, R., and von Hagen, J. (1998), Sustainable Public Finances, CEPR, Centre for Economic Policy Research, London.

POPOKP (2005), “4 Billion Euro Social Security Tax Evasion, More than 1 Million the Uninsured”, May-June Issue of the Journal, pp. 10-15 (in Greek).

Psacharopoulos, G., and Papakonstantinou, G. (2005), The real university cost in a "free" higher education country, Economics of Education Review 24, pp. 103-108.

Rausch, J.E.,(1991), "Modelling the Informal Sector Formally", Journal of Development Economics, 35, pp.33-47.

Schneider, F. (2006), Shadow Economies and Corruption All Over the World:What Do We Really Know? IZA Discussion Paper No. 2315, Institute for the Study of Labor, Bonn.

Schneider, F., Enste, D. (2000), “ Shadow economies: Size, causes, and consequences”, Journal of Economic Literature, 38/1, pp. 77-114.

State Audit Council (2008), State Audit Council Report, November (in Greek).

Tatsos, N. (2001) Shadow economy and tax evasion in Greece. IOBE, Athens (in Greek).

Tsakalotos, E. (1998), “The Political Economy of Social Democratic Economic Policies: the PASOK Experiment in Greece”, Oxford Review of Economic Policy, vol. 14 (1), pp. 114-38.

Tsakalotos, E. (2005), The Values and the Value of the Left, Kritiki, Athens (in Greek).

van der Ploeg, F. (1997), Prudent Budgetary Policy: Political Economy of Precautionary Taxation, CESifo Working Paper No. 1973, Munich.

von Hagen, J. and Strauch, R. (2001), "Fiscal Consolidations: Quality, Economic Conditions and Success”, Public Choice, 109, pp. 327-346.

von Hagen, J., (2005), Fiscal Rules and Fiscal Performance in the EU and Japan, CEPR Discussion Paper, No. 5330, Centre for Economic Policy Research, London.

Zervou, F. (2009), Evolution and pondering on the sustainability of the pension system, Report No 58, KEPE, Athens (in Greek).

Corresponding Author:

Thomas Moutos

Department of International and European Economic Studies,

Athens University of Economics and Business, Patission 76, Athens 104 34, Greece.

Email: tmoutos@aueb.gr 
Figure 1: Evolution of Greek per capita GDP at 2000 constant prices (Euros)

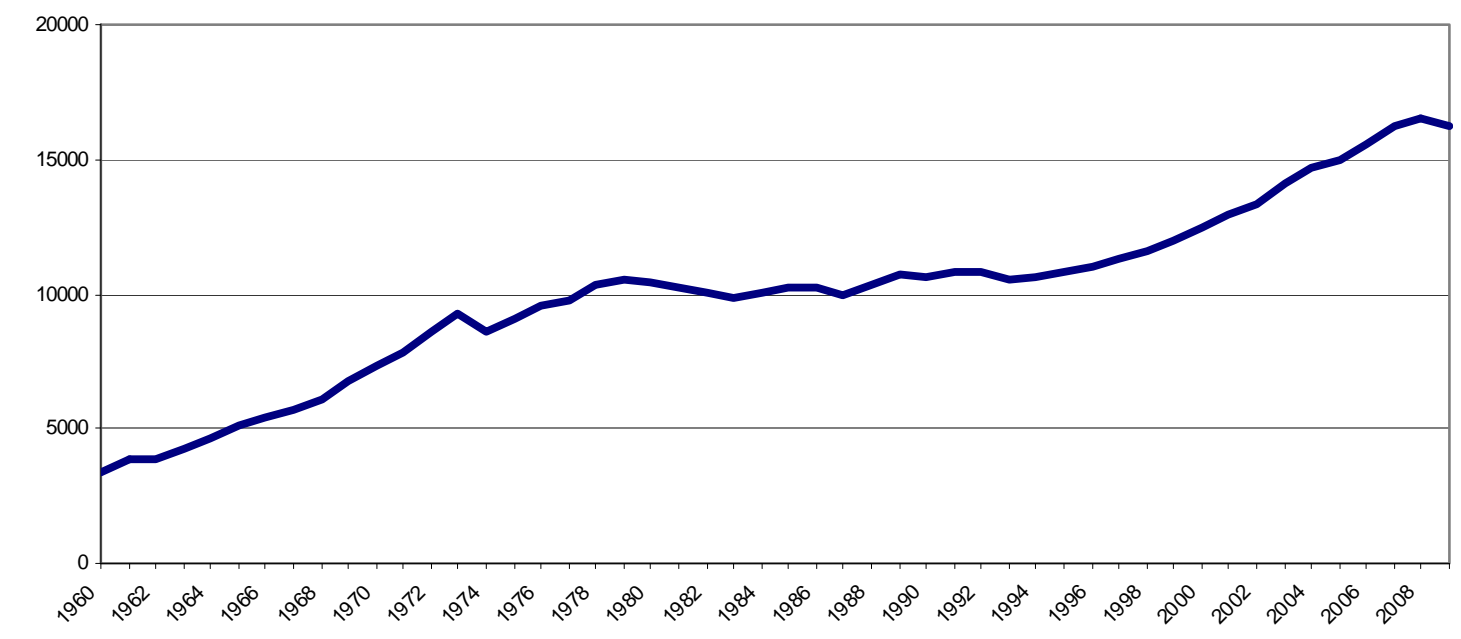

Source: Ameco 
Figure 2: Greek GDP per capita relative to EU15 and the peripheral 4 (Ireland, Italy, Spain, Portugal)

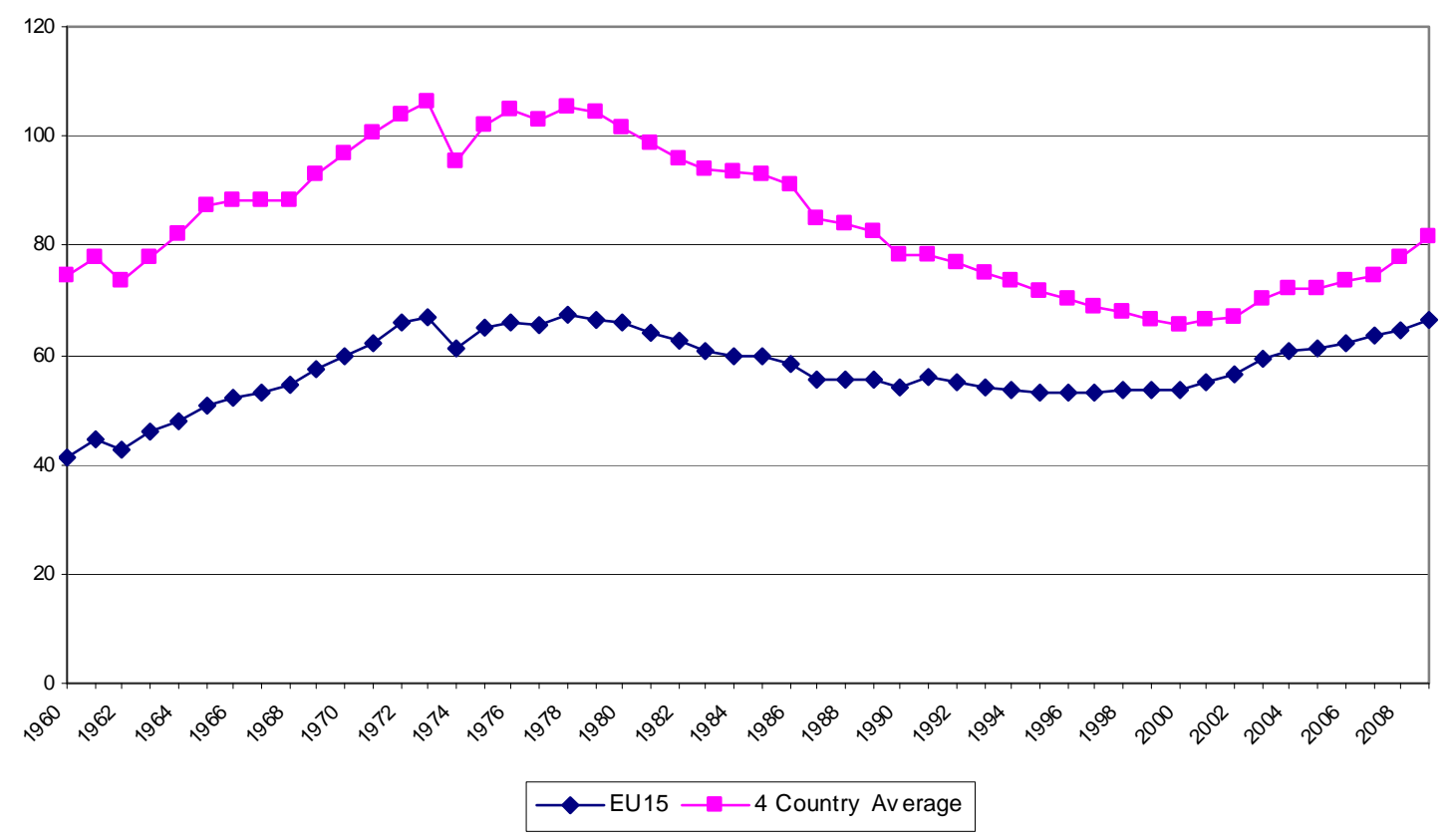

Source: Ameco 
Figure 3: Debt and Deficits

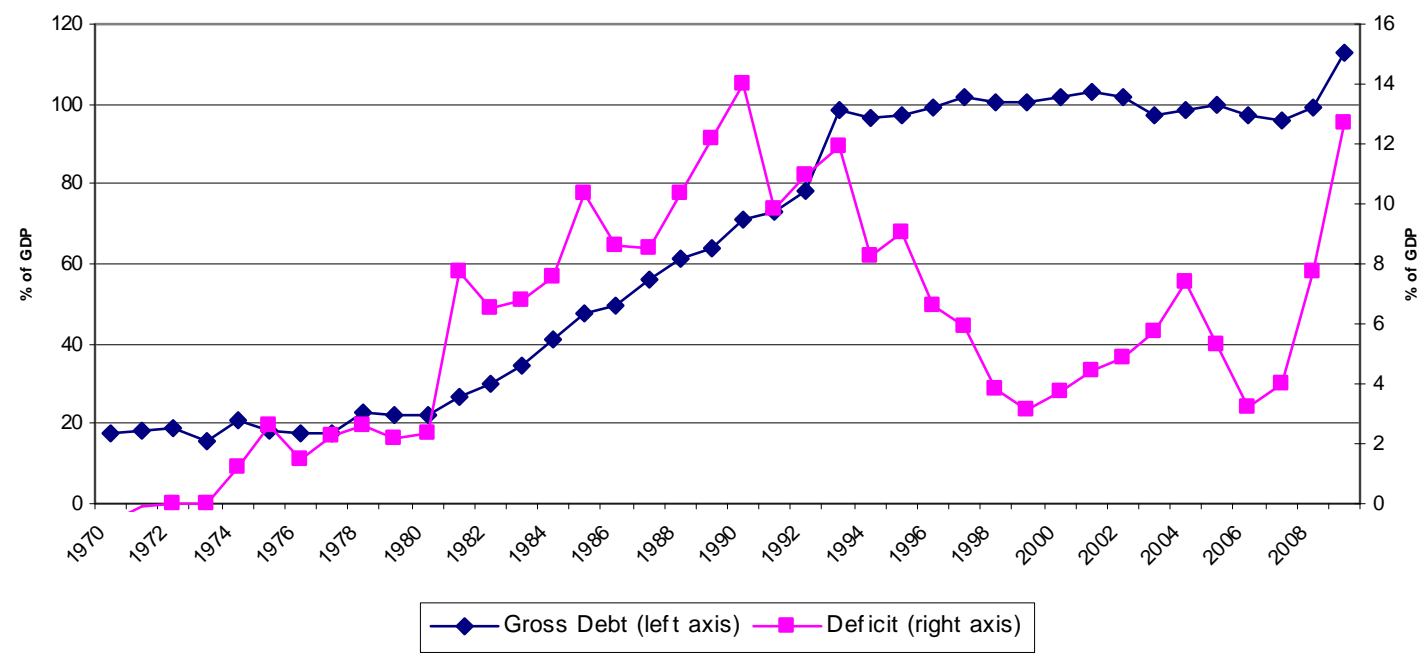

Source: Ameco, OECD 
Figure 4: Gross National Saving - \% GDP

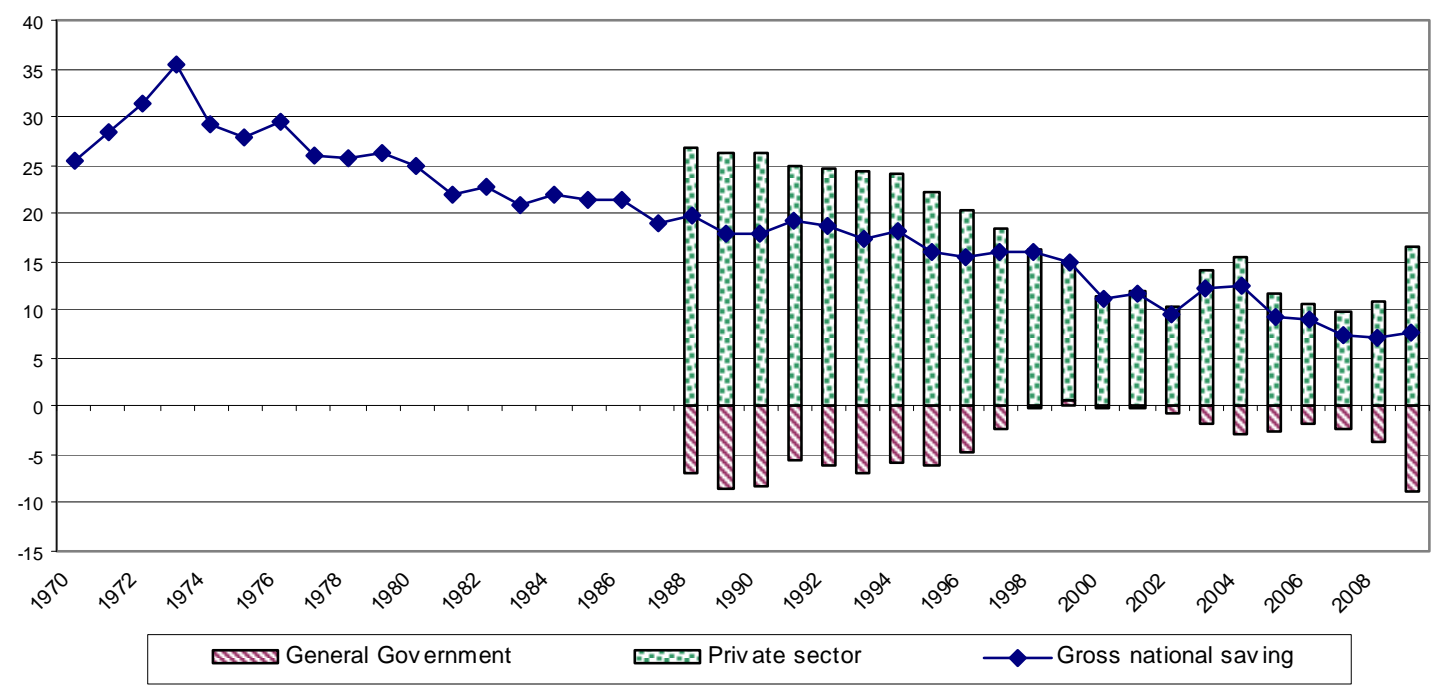

Source: Ameco 
Figure 5: Net National Saving - \% GDP

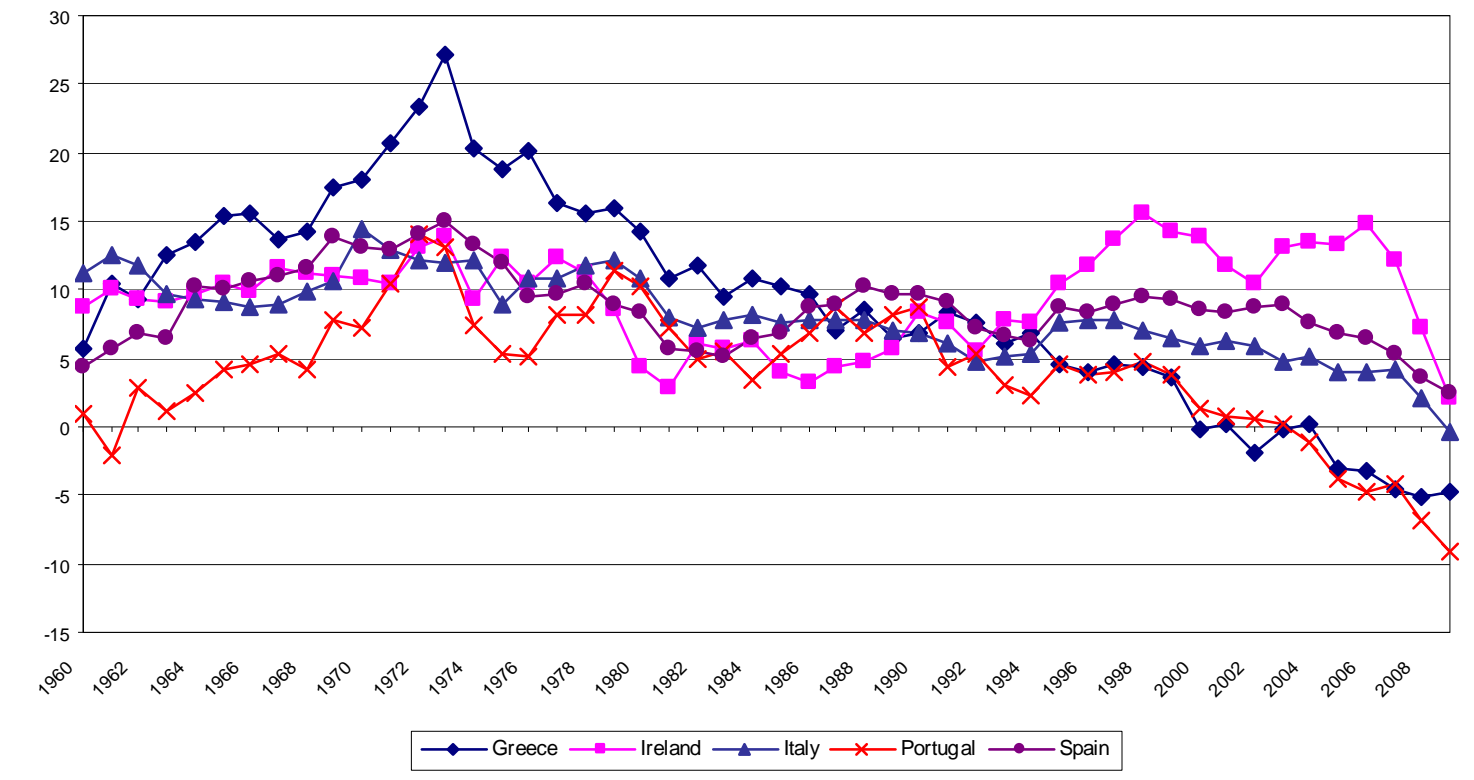

Source: Ameco 
Figure 6: Greek Current Account (\% of GDP)

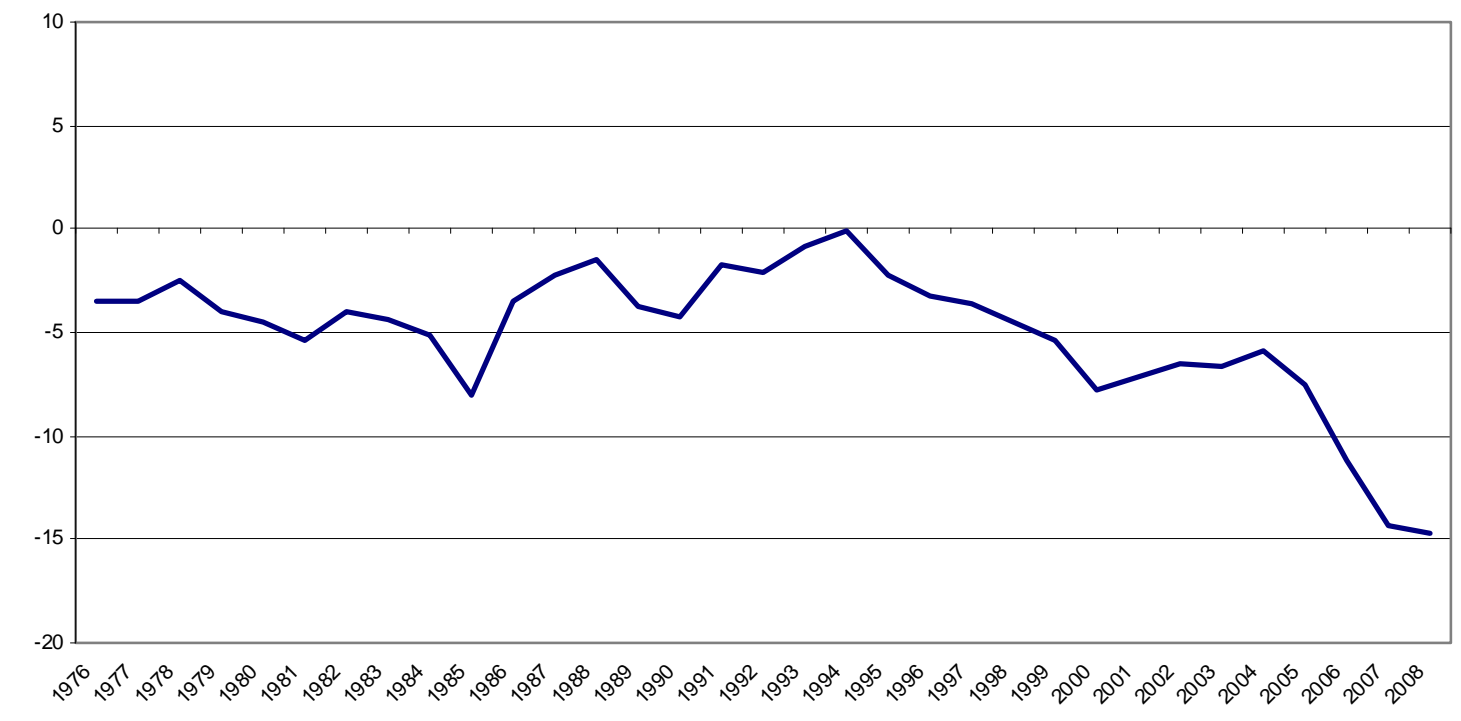

Source: IMF 
Figure 7: Debt Decomposition

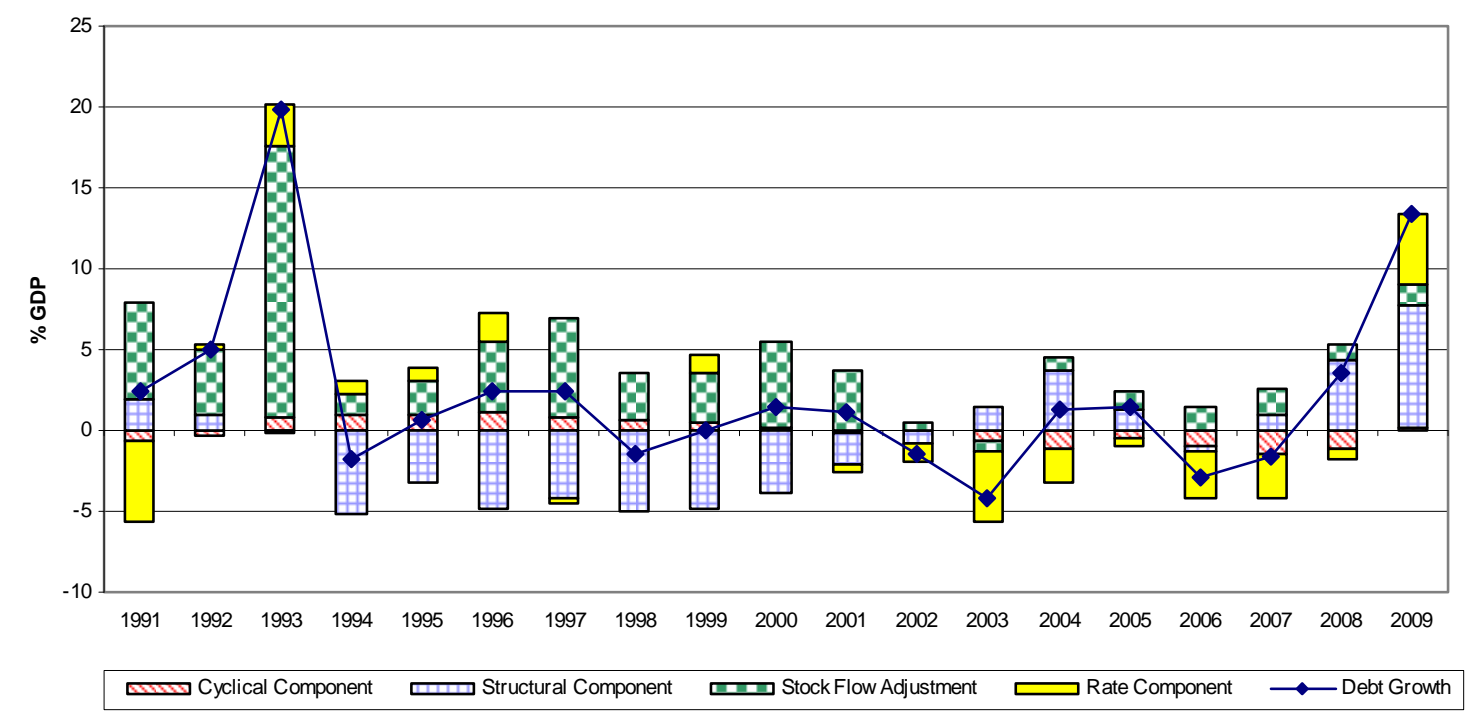

Source: Ameco 
Figure 8: Debt Decomposition - Compound Effect

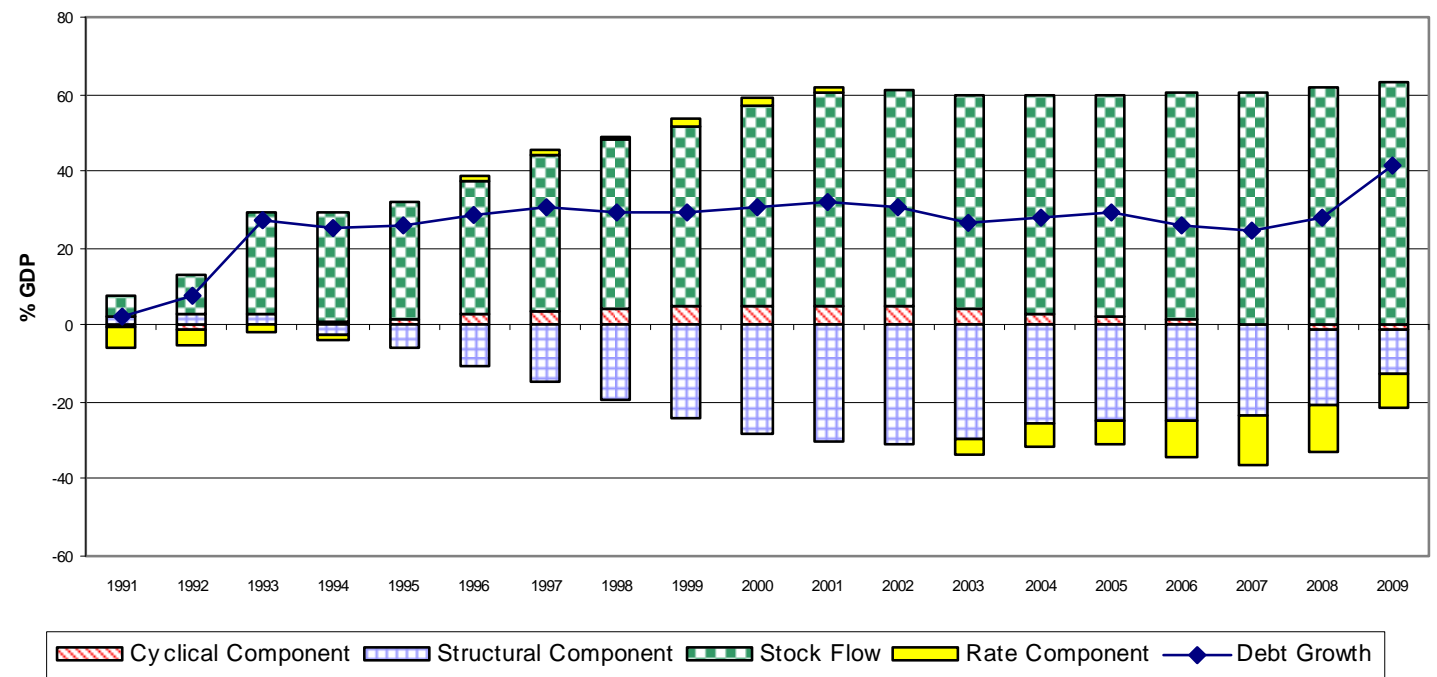

Source: Ameco 
Figure 9: Debt Decomposition - Redefined Structural Component

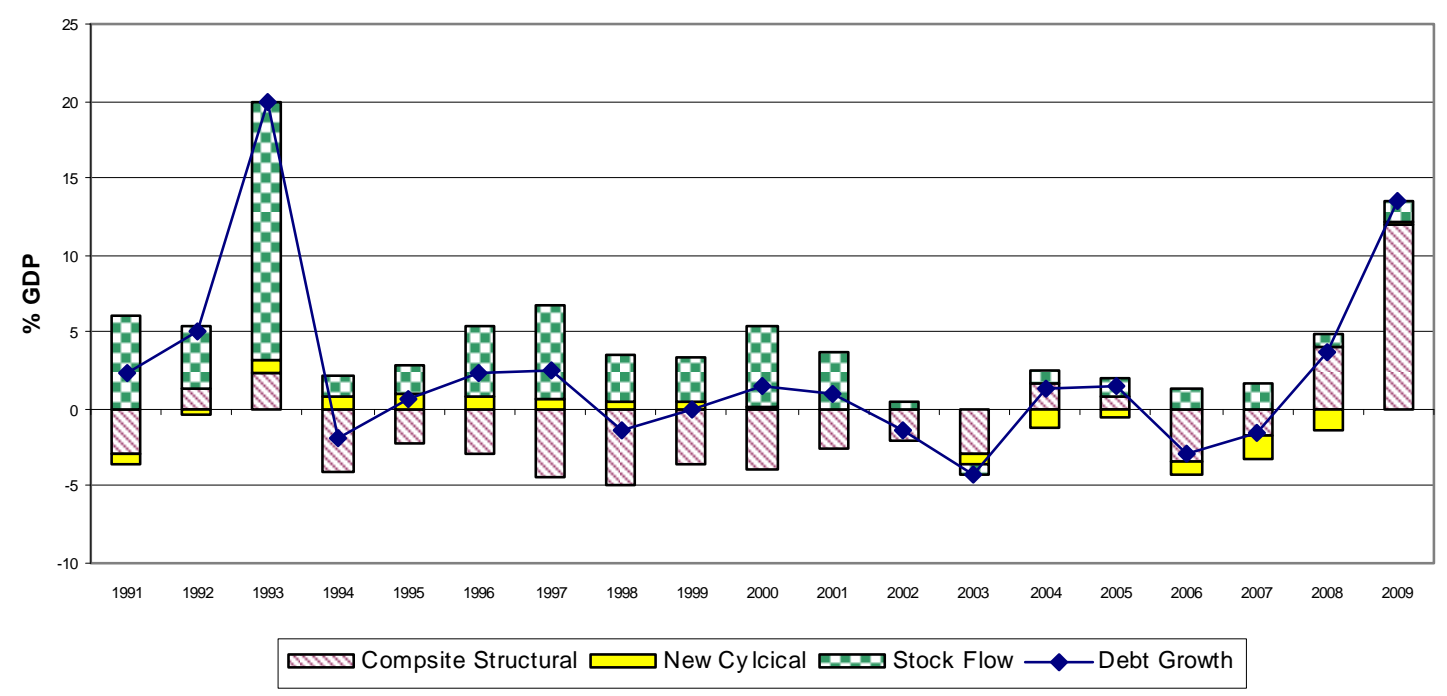

Source: Ameco 
Figure 10: Expenditures - \% of GDP

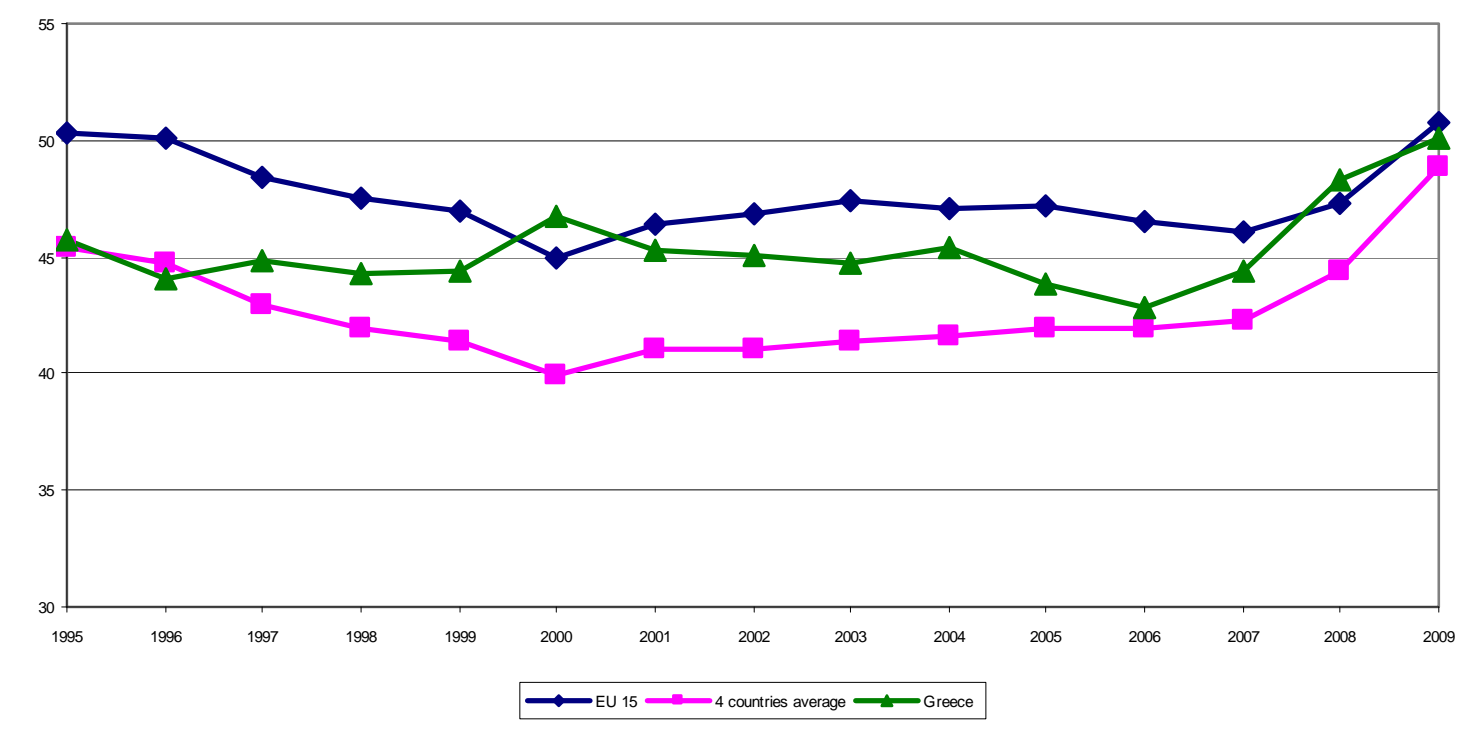

Source: Ameco 
Figure 11: The Evolution of Wages in the Private and Public Sectors, Greece (1995=100)

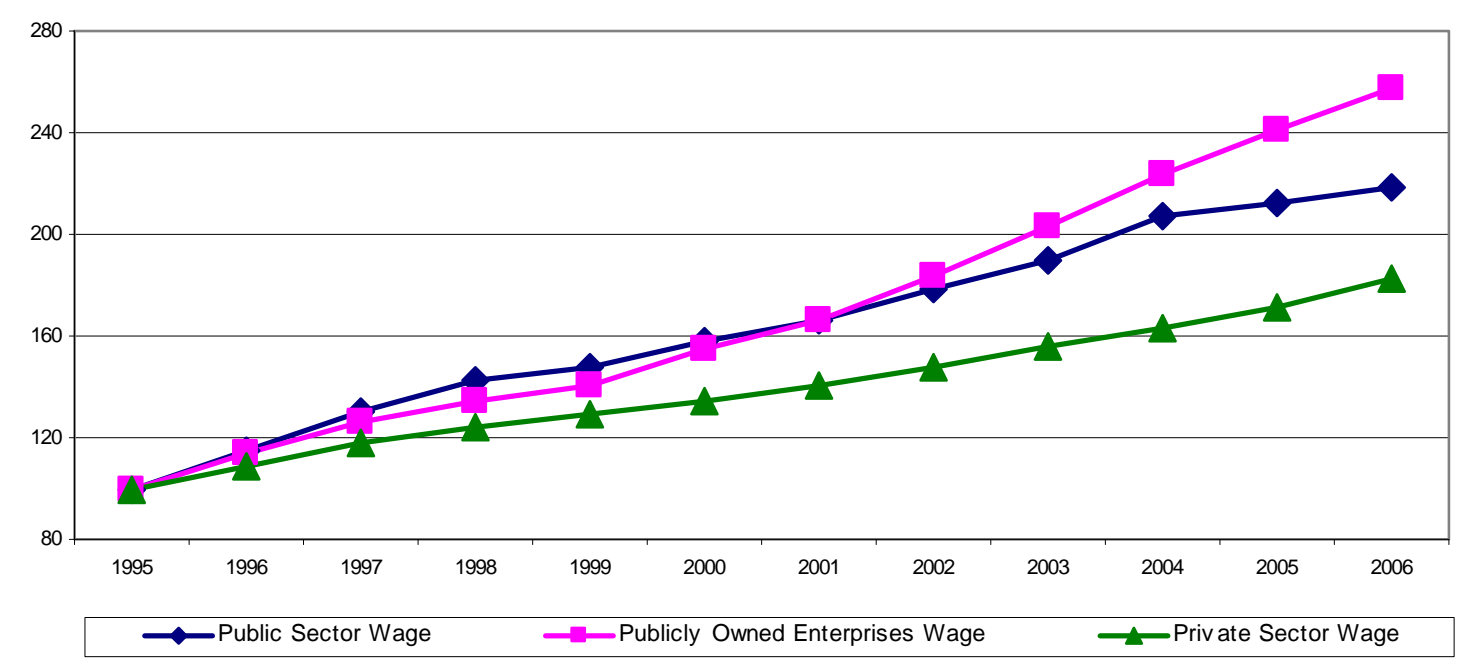

Source: ESYE, Bank of Greece, and authors' calculations 
Figure 12: Government Revenue - \% of GDP

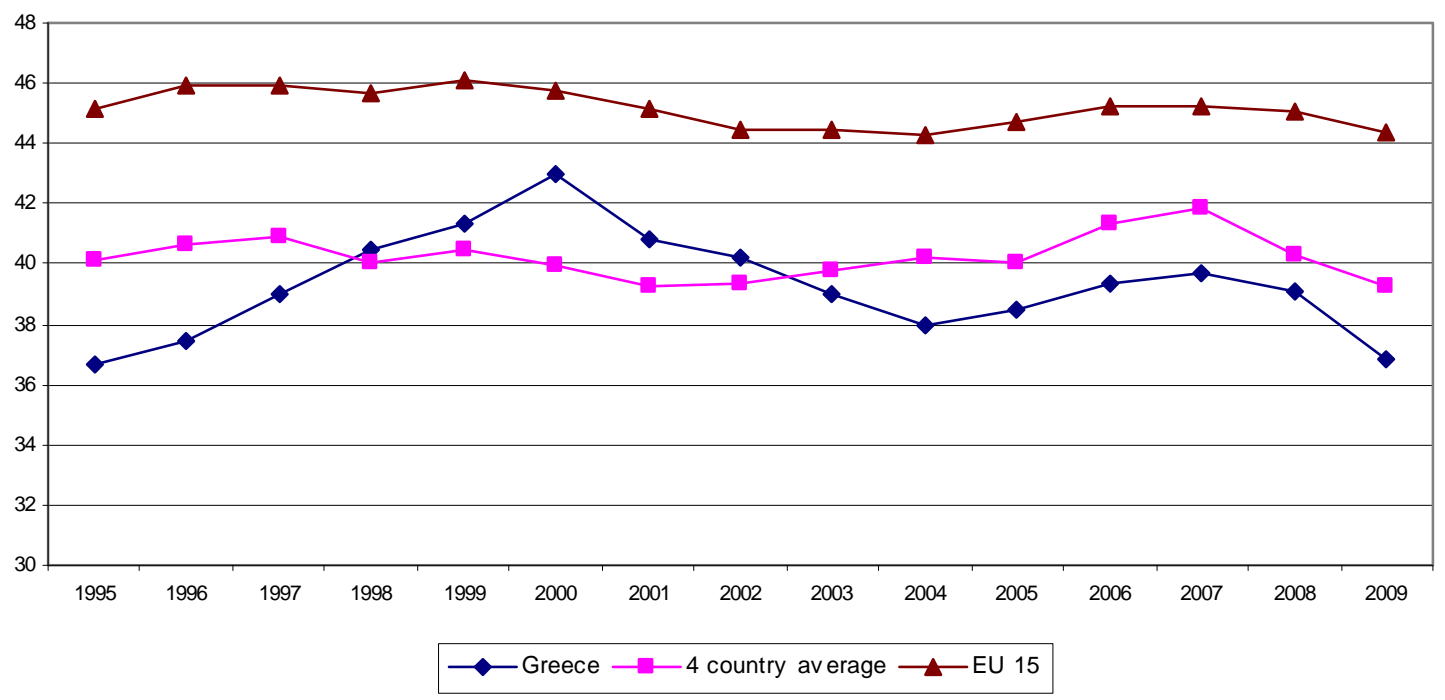

Source: Ameco 
Figure 13: Sources of tax revenue (\% of total tax revenue)

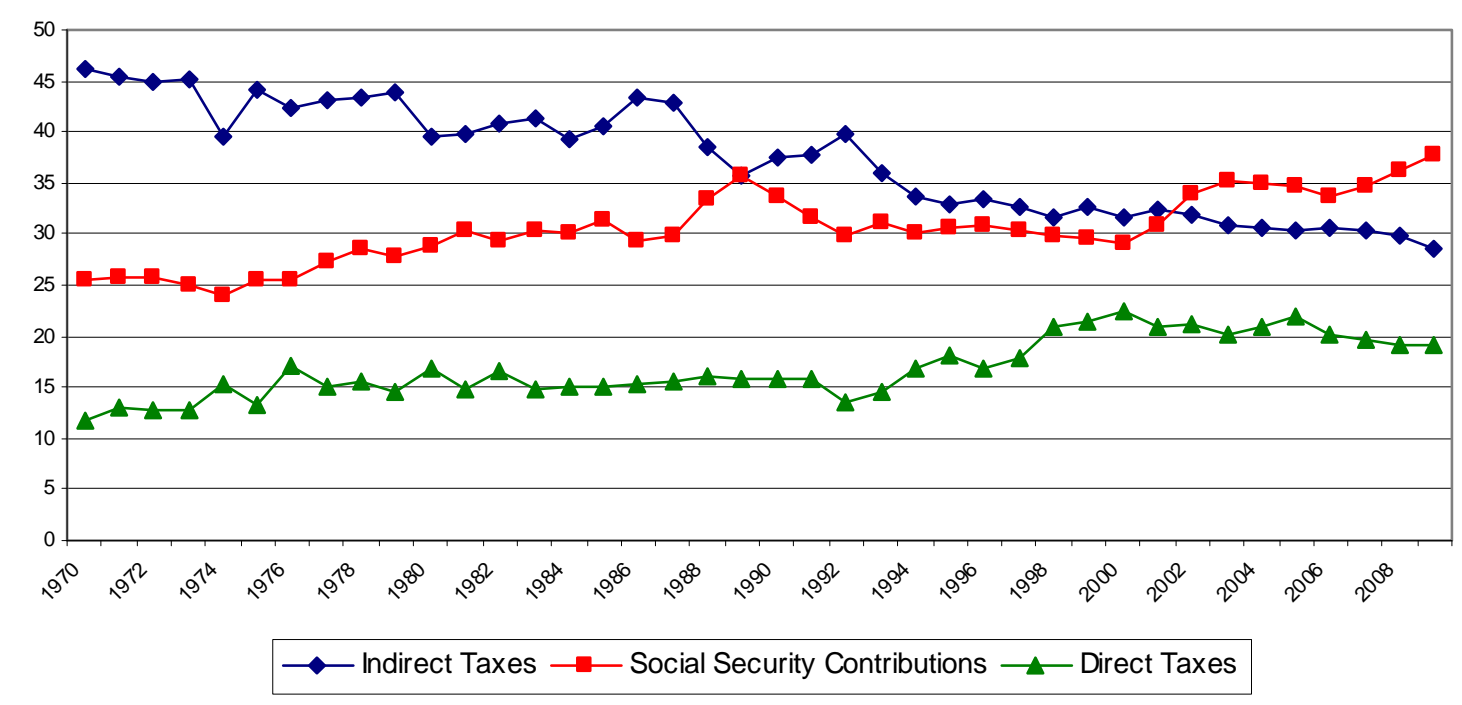

Source: OECD 
Table 1. Age-related government expenditure, 2007-2060, \% of GDP

\begin{tabular}{|c|c|c|c|c|}
\hline & & Greece & EU27 & Euro-area \\
\hline \multirow{3}{*}{ Pensions } & Level 2007 & 11.7 & 10.2 & 11.1 \\
\hline & Change 20072035 & 7.7 & 1.7 & 2.1 \\
\hline & Change 20072060 & 12.4 & 2.4 & 2.8 \\
\hline \multirow{3}{*}{ Health care } & Level 2007 & 5.0 & 6.7 & 6.7 \\
\hline & Change 20072035 & 0.9 & 1.0 & 1.0 \\
\hline & Change 20072060 & 1.4 & 1.5 & 1.4 \\
\hline \multirow{3}{*}{$\begin{array}{l}\text { Long-term } \\
\text { care }\end{array}$} & Level 2007 & 1.4 & 1.2 & 1.3 \\
\hline & Change 20072035 & 0.8 & 0.6 & 0.7 \\
\hline & Change 20072060 & 2.2 & 1.1 & 1.4 \\
\hline \multirow{3}{*}{$\begin{array}{l}\text { Unemployment } \\
\text { benefits }\end{array}$} & Level 2007 & 0.3 & 0.8 & 1.0 \\
\hline & Change 20072035 & -0.1 & -0.2 & -0.2 \\
\hline & Change 20072060 & -0.1 & -0.2 & -0.2 \\
\hline \multirow{3}{*}{ Education } & Level 2007 & 3.7 & 4.3 & 4.2 \\
\hline & Change 20072035 & -0.3 & -0.3 & -0.3 \\
\hline & Change 20072060 & 0.0 & -0.2 & -0.2 \\
\hline \multirow{3}{*}{ Total } & Level 2007 & 22.1 & 23.1 & 24.3 \\
\hline & Change 20072035 & 9.1 & 2.7 & 3.2 \\
\hline & Change 20072060 & 15.9 & 4.7 & 5.2 \\
\hline
\end{tabular}

Source: Commission Services, EPC 


\section{CESifo Working Paper Series}

for full list see www.cesifo-group.org/wp

(address: Poschingerstr. 5, 81679 Munich, Germany, office@cesifo.de)

3037 Eric A. Hanushek and Ludger Woessmann, The Economics of International Differences in Educational Achievement, April 2010

3038 Frederick van der Ploeg, Aggressive Oil Extraction and Precautionary Saving: Coping with Volatility, April 2010

3039 Ainura Uzagalieva, Evžen Kočenda and Antonio Menezes, Technological Imitation and Innovation in New European Union Markets, April 2010

3040 Nicolas Sauter, Jan Walliser and Joachim Winter, Tax Incentives, Bequest Motives, and the Demand for Life Insurance: Evidence from two Natural Experiments in Germany, April 2010

3041 Matthias Wrede, Multinational Capital Structure and Tax Competition, April 2010

3042 Burkhard Heer and Alfred Maussner, A Note on the Computation of the Equity Premium and the Market Value of Firm Equity, April 2010

3043 Kristiina Huttunen, Jukka Pirttilä and Roope Uusitalo, The Employment Effects of Low-Wage Subsidies, May 2010

3044 Matthias Kalkuhl and Ottmar Edenhofer, Prices vs. Quantities and the Intertemporal Dynamics of the Climate Rent, May 2010

3045 Bruno S. Frey and Lasse Steiner, Pay as you Go: A New Proposal for Museum Pricing, May 2010

3046 Henning Bohn and Charles Stuart, Population under a Cap on Greenhouse Gas Emissions, May 2010

3047 Balázs Égert and Rafal Kierzenkowski, Exports and Property Prices in France: Are they Connected?, May 2010

3048 Thomas Eichner and Thorsten Upmann, Tax-Competition with Involuntary Unemployment, May 2010

3049 Taiji Furusawa, Kazumi Hori and Ian Wooton, A Race beyond the Bottom: The Nature of Bidding for a Firm, May 2010

3050 Xavier Vives, Competition and Stability in Banking, May 2010

3051 Thomas Aronsson and Erkki Koskela, Redistributive Income Taxation under Outsourcing and Foreign Direct Investment, May 2010 
3052 Michael Melvin and Duncan Shand, Active Currency Investing and Performance Benchmarks, May 2010

3053 Sören Blomquist and Laurent Simula, Marginal Deadweight Loss when the Income Tax is Nonlinear, May 2010

3054 Lukas Menkhoff, Carol L. Osler and Maik Schmeling, Limit-Order Submission Strategies under Asymmetric Information, May 2010

3055 M. Hashem Pesaran and Alexander Chudik, Econometric Analysis of High Dimensional VARs Featuring a Dominant Unit, May 2010

3056 Rabah Arezki and Frederick van der Ploeg, Do Natural Resources Depress Income Per Capita?, May 2010

3057 Joseph Plasmans and Ruslan Lukach, The Patterns of Inter-firm and Inter-industry Knowledge Flows in the Netherlands, May 2010

3058 Jenny E. Ligthart and Sebastian E. V. Werner, Has the Euro Affected the Choice of Invoicing Currency?, May 2010

3059 Håkan Selin, Marginal Tax Rates and Tax-Favoured Pension Savings of the SelfEmployed - Evidence from Sweden, May 2010

3060 Richard Cornes, Roger Hartley and Yuji Tamura, A New Approach to Solving Production-Appropriation Games with Many Heterogeneous Players, May 2010

3061 Ronald MacDonald and Flávio Vieira, A Panel Data Investigation of Real Exchange Rate Misalignment and Growth, May 2010

3062 Thomas Eichner and Rüdiger Pethig, Efficient Management of Insecure Fossil Fuel Imports through Taxing(!) Domestic Green Energy?, May 2010

3063 Vít Bubák, Evžen Kočenda and Filip Žikeš, Volatility Transmission in Emerging European Foreign Exchange Markets, May 2010

3064 Leonid V. Azarnert, Après nous le Déluge: Fertility and the Intensity of Struggle against Immigration, May 2010

3065 William E. Becker, William H. Greene and John J. Siegfried, Do Undergraduate Majors or Ph.D. Students Affect Faculty Size?, May 2010

3066 Johannes Becker, Strategic Trade Policy through the Tax System, May 2010

3067 Omer Biran and Françoise Forges, Core-stable Rings in Auctions with Independent Private Values, May 2010

3068 Torben M. Andersen, Why do Scandinavians Work?, May 2010 
3069 Andrey Launov and Klaus Wälde, Estimating Incentive and Welfare Effects of NonStationary Unemployment Benefits, May 2010

3070 Simon Gächter, Benedikt Herrmann and Christian Thöni, Culture and Cooperation, June 2010

3071 Mehmet Bac and Eren Inci, The Old-Boy Network and the Quality of Entrepreneurs, June 2010

3072 Krisztina Molnár and Sergio Santoro, Optimal Monetary Policy when Agents are Learning, June 2010

3073 Marcel Boyer and Donatella Porrini, Optimal Liability Sharing and Court Errors: An Exploratory Analysis, June 2010

3074 Guglielmo Maria Caporale, Roman Matousek and Chris Stewart, EU Banks Rating Assignments: Is there Heterogeneity between New and Old Member Countries? June 2010

3075 Assaf Razin and Efraim Sadka, Fiscal and Migration Competition, June 2010

3076 Shafik Hebous, Martin Ruf and Alfons Weichenrieder, The Effects of Taxation on the Location Decision of Multinational Firms: M\&A vs. Greenfield Investments, June 2010

3077 Alessandro Cigno, How to Deal with Covert Child Labour, and Give Children an Effective Education, in a Poor Developing Country: An Optimal Taxation Problem with Moral Hazard, June 2010

3078 Bruno S. Frey and Lasse Steiner, World Heritage List: Does it Make Sense?, June 2010

3079 Henning Bohn, The Economic Consequences of Rising U.S. Government Debt: Privileges at Risk, June 2010

3080 Rebeca Jiménez-Rodriguez, Amalia Morales-Zumaquero and Balázs Égert, The VARying Effect of Foreign Shocks in Central and Eastern Europe, June 2010

3081 Stephane Dees, M. Hashem Pesaran, L. Vanessa Smith and Ron P. Smith, Supply, Demand and Monetary Policy Shocks in a Multi-Country New Keynesian Model, June 2010

3082 Sara Amoroso, Peter Kort, Bertrand Melenberg, Joseph Plasmans and Mark Vancauteren, Firm Level Productivity under Imperfect Competition in Output and Labor Markets, June 2010

3083 Thomas Eichner and Rüdiger Pethig, International Carbon Emissions Trading and Strategic Incentives to Subsidize Green Energy, June 2010

3084 Henri Fraisse, Labour Disputes and the Game of Legal Representation, June 2010 
3085 Andrzej Baniak and Peter Grajzl, Interjurisdictional Linkages and the Scope for Interventionist Legal Harmonization, June 2010

3086 Oliver Falck and Ludger Woessmann, School Competition and Students' Entrepreneurial Intentions: International Evidence Using Historical Catholic Roots of Private Schooling, June 2010

3087 Bernd Hayo and Stefan Voigt, Determinants of Constitutional Change: Why do Countries Change their Form of Government?, June 2010

3088 Momi Dahan and Michel Strawczynski, Fiscal Rules and Composition Bias in OECD Countries, June 2010

3089 Marcel Fratzscher and Julien Reynaud, IMF Surveillance and Financial Markets - A Political Economy Analysis, June 2010

3090 Michel Beine, Elisabetta Lodigiani and Robert Vermeulen, Remittances and Financial Openness, June 2010

3091 Sebastian Kube and Christian Traxler, The Interaction of Legal and Social Norm Enforcement, June 2010

3092 Volker Grossmann, Thomas M. Steger and Timo Trimborn, Quantifying Optimal Growth Policy, June 2010

3093 Huw David Dixon, A Unified Framework for Using Micro-Data to Compare Dynamic Wage and Price Setting Models, June 2010

3094 Helmuth Cremer, Firouz Gahvari and Pierre Pestieau, Accidental Bequests: A Curse for the Rich and a Boon for the Poor, June 2010

3095 Frank Lichtenberg, The Contribution of Pharmaceutical Innovation to Longevity Growth in Germany and France, June 2010

3096 Simon P. Anderson, Øystein Foros and Hans Jarle Kind, Hotelling Competition with Multi-Purchasing: Time Magazine, Newsweek, or both?, June 2010

3097 Assar Lindbeck and Mats Persson, A Continuous Theory of Income Insurance, June 2010

3098 Thomas Moutos and Christos Tsitsikas, Whither Public Interest: The Case of Greece's Public Finance, June 2010 